Board of Governors of the Federal Reserve System

International Finance Discussion Papers

Number 1117

September 2014

\title{
Bank Interventions and Options-based Systemic Risk: Evidence from the Global and Euro-area Crisis
}

\author{
Juan M. Londono Mary Tian
}

Board of Governors of the Federal Reserve System

NOTE: International Finance Discussion Papers are preliminary materials circulated to stimulate discussion and critical comment. References to International Finance Discussion Papers (other than an acknowledgment that the writer has had access to unpublished material) should be cleared with the author or authors. Recent IFDPs are available on the Web at www.federalreserve.gov/pubs/ifdp/. This paper can be downloaded without charge from Social Science Research Network electronic library at www.ssrn.com. 


\title{
Bank Interventions and Options-based Systemic Risk: Evidence from the Global and Euro-area Crisis *
}

\author{
Juan M. Londono ${ }^{\dagger} \quad$ Mary Tian ${ }^{\ddagger}$ \\ This Version: September 4, 2014
}

\begin{abstract}
Using a novel dataset on central bank interventions to financial institutions, we examine the impact of capital injection announcements on systemic risk for the banking sector in the U.S. and the euro area between 2008 and 2013. We propose a new measure of options-based systemic risk called downside correlation risk premium (DCRP), which quantifies the compensation investors demand for being exposed to the risk of large correlated drops in bank stock prices. DCRP is calculated using options that provide a hedge against large drops in the price of a bank index and its individual components. We find that, irrespective of their characteristics, intervention announcements significantly reduce DCRP in the U.S. while for the euro area, interventions were largely unsuccessful at reducing DCRP.
\end{abstract}

Keywords: Systemic Risk, Downside Correlation Risk Premium, Bank Interventions, Variance Risk Premium, European Banking Union. JEL Classification: G15, G21, G28, F36

*The views in this paper are solely the responsibility of the authors and should not be interpreted as reflecting the views of the Board of Governors of the Federal Reserve System or of any other person associated with the Federal Reserve System. An earlier version of this paper was circulated under the title "Do Agents Believe in Euro-area Bank Interventions? An Options-Based Risk Approach." We thank conference participants at the Fed's System Committee Conference on International Economic Analysis, the IBEFA summer meeting, the Austrian National Bank's Transatlantic Conference on Banks, and the IFSID and Bank of Canada Conference on Derivatives. We thank Michael Zdinak for excellent research assistance and Michael Zdinak, Clara Vega, and Juan M. Londono for providing SRisk measures.

${ }^{\dagger}$ International Finance Division, Federal Reserve Board, Mail Stop 43, Washington DC 20551, USA; E-mail juan-miguel.londono-yarce@frb.gov, Phone 202-973-7478.

${ }^{\ddagger}$ International Finance Division, Federal Reserve Board, Mail Stop 43, Washington DC 20551, USA; E-mail Mary.Tian@frb.gov, Phone 202-452-3661. 


\section{Introduction}

The global financial crisis of 2008 and the subsequent European debt crisis highlighted the need to understand the effectiveness of central bank interventions on systemically important financial institutions (SIFIs). Since 2008, central banks worldwide have spent billions on capital injections into financial institutions, in an attempt to prevent a collapse of the banking system, which would have had disastrous effects for the global economy. In this paper, we investigate how effective capital injection announcements are in alleviating how investors perceive systemic risk for the banking sector. We also explore what makes some interventions more or less successful than others at reducing systemic risk, and why the effectiveness of interventions differ between the U.S. and the euro area.

Our contribution is twofold. First, we propose a new options-based measure of systemic risk for the banking sector, called downside correlation risk premium (DCRP), which is based on the prices of out-of-the-money options on bank indexes and their individual components. Our measure stems from the correlation risk premium literature and quantifies the compensation investors demand for being exposed to the risk of large correlated drops in bank stock prices. Specifically, DCRP is computed as the difference in the premium that agents demand for bearing downside variance risk in the bank index versus the average downside variance risk premium of all individual banks within the index. Thus, DCRP can be interpreted as a risk-neutral measure of common system-wide risk. Moreover, following the intuition in Kelly, Lustig, and Nieuwerburgh (2012), DCRP might also implicitly measure investors' expectations of government interventions in the financial sector - an insignificant DCRP indicates that agents do not demand a premium for being exposed to correlation risk, possibly because they expect a government bailout of SIFIs to prevent a system-wide failure.

We calculate our options-based measure of systemic risk, DCRP, for the U.S. and the euro area for a sample running from 2008 to 2013. DCRP is on average negative and significant in the U.S.. In particular, U.S. DCRP has a large negative magnitude in the fall of 2008, when the bulk of U.S. bank interventions occurred. Given that DCRP is the difference in the downside variance risk premium of the bank index and the average downside variance risk premium of individual banks, our results suggest that investors became relatively less concerned about the bank index's downside variance risk than individual banks' downside variance risk, in light of the government interventions. In contrast, the DCRP for euro-area banks is on average positive and significant over our sample period, suggesting that investors are still willing to pay a premium to hedge downside systemic risk in the euro-area banking system, despite interventions by euro-area member states.

In our second main contribution, we use a unique dataset on bank intervention announcements to document whether and how interventions alleviate DCRP. The database provides details on all stand-alone actions and programs announced from September 2008 to December 2013 in 29 countries, including the U.S. and individual euro-area countries. We define a time-series dummy variable for government interventions on financial institutions, which takes a value of 1 on the days when capital injections were announced and 0 otherwise. In addition, to account for the unexpected component of each intervention announcement, we also construct an intervention surprise measure, which takes a value between 0 and 1 depending on the impact of the capital injection announcement on the stock price of the specific bank being intervened.

For the U.S. and the euro area, we regress DCRP on the interventions dummy or the 
interventions surprise measure. Our regression results highlight important differences in the effects of intervention announcements on our options-based measures of systemic risk in the U.S. versus the euro area. Specifically, we find that intervention announcements in the U.S. have a significant and economically meaningful impact on reducing DCRP between the country's banks, while intervention announcements in the euro area have an insignificant effect at reducing DCRP. We find that these results on the effectiveness of intervention announcements are robust to considering alternative sample periods, controlling for liquidity and the informational content of options, and to different magnitudes of downside risk (degrees of options' moneyness). We also confirm that our regression results are robust to categories of financial sector support measures other than capital injections (deposit insurance, debt guarantees, asset relief measures, and credit market interventions).

Our findings allow us to make interesting comparisons about the effect of bank intervention announcements, especially as European authorities make substantial progress towards a banking union. Although by the end of 2012, European leaders had already agreed upon the Single Supervisory Mechanism (SSM) involving the European Central Bank (ECB), which opened the possibility of direct pan-European interventions, interventions on euro-area financial institutions were still done by local authorities in the member states. One of the main goals of the proposed banking union is precisely to improve investors' confidence and minimize the segmentation between interventions on specific euro-area banks and its effects on perceived risk in the euro area as a whole.

In addition to examining the effect of intervention announcements on our measure of systemic risk, we also analyze which characteristics make interventions more or less successful in reducing DCRP. In particular, we investigate the effect on DCRP of interventions that involved banks from multiple countries, multiple banks, banks that were included in stress tests, banks that are in the country/region's bank index, banks with large market capitalizations, banks that received a large capital injection amount, and banks that have a large SRisk. We find that, irrespective of these characteristics, interventions in the U.S. are successful at alleviating DCRP, while for the euro area, only interventions that involved multiple banks have a significant effect in reducing DCRP. For the euro area, we also analyze the effect of country-specific interventions on the region's DCRP. We find that euro-area authorities' bank interventions appear segmented to investors. In particular, interventions by each member state have an insignificant differential effect on the euro-area DCRP. Moreover, countryspecific bank interventions do seem to have an effect on the downside variance risk premium of individual banks, but this effect is economically meaningful only for banks within the intervening country but not for euro-area banks outside the intervening country.

The rest of the paper is organized as follows. Section 2 describes the related literature. Section 3 describes the data and methodology. Section 4 compares the effects of U.S. and euroarea bank intervention announcements. Section 5 investigates which types of interventions are more successful in alleviating DCRP. Section 6 concludes.

\section{Related Literature}

Our paper contributes to three strands of literature. First, our paper contributes to the systemic risk literature; in particular, to a recent literature that studies the use of financial variables to measure systemic risk. Second, our paper contributes to the variance and 
correlation risk premium literature that uses option prices to measure the compensation that investors demand for bearing the risk of extreme individual or system-wide events. Finally, our paper also contributes to the literature on the effect of macroprudential policies; in particular, government interventions on financial institutions.

The literature on systemic risk measures has proliferated in recent years as macroprudential policies took center stage, especially after the collapse of Lehman Brothers in October 2009 (see Brandt and Hartmann, 2000 and Bisias, Flood, Lo, and Valavanis, 2012 for a survey of systemic risk measures). More recently, several papers have proposed measures of systemic risk based on financial variables, which have the advantage of being publicly available and at a higher frequency than more traditional balance-sheet data. The CoVaR of Adrian and Brunnermeier (2011) is a measure of the contribution of an individual institution to the overall systemic risk calculated using individual and market stock returns. Acharya, Pedersen, Philippon, and Richardson (2010) propose a static framework to measure an institution's expected capital shortfall conditioned on a substantial market decline. Brownless and Engle (2012) build on this framework and propose a method to calculate time-varying expected capital shortfall that can be used as a measure of ex-ante systemic risk. The measure in Brownless and Engle (2012) can be aggregated to obtain a measure of overall systemic risk, which they show is a good predictor for recessions. Huang, Zhou, and Zhu (2009, 2012) also propose an aggregate measure of systemic risk calculated using individual institutions' probabilities of defaults derived from CDS and equity return correlations across financial institutions. We propose an aggregate measure of systemic risk in the banking system, calculated using options that provide a hedge against large drops in the price of a bank index and of individual institutions. Thus, as the measure in Huang et al. (2009, 2012), our measure involves investors' attitudes toward risk and is therefore a risk-neutral measure.

Our measure of systemic risk stems from the variance risk premium and correlation risk premium literature, and quantifies the compensation investors demand for being exposed to the risk of large correlated drops in bank stock prices. Bakshi and Madan (2006) link the variance risk premium to the desire of risk-averse agents to buy protection against extreme events. Bekaert and Engstrom (2009), Todorov (2010), and Gabaix (2012) also rely on the interplay between risk aversion and extreme events to explain the variance risk premium. There is extensive evidence that the variance risk of headline indexes is priced in stock markets (see, for instance, Britten-Jones and Neuberger, 2000; Jiang and Tian, 2005; Bakshi and Madan, 2006; Carr and Wu, 2009; Bollerslev, Gibson, and Zhou, 2011; Bollerslev, Tauchen, and Zhou, 2009; Londono, 2011; and Bollerslev et al., 2011). However, Bakshi and Kapadia (2003) establish that the stock-specific variance risk premium is insignificant, or at least much smaller than the index's variance risk premium. In other words, in order to hedge correlation risk, agents are willing to pay more for index options than for individual stock options. Duan and Wei (2009) establish a significant link between the price structure of individual stock options and the amount of systematic risk in the underlying assets. Schurhoff and Ziegler (2011) decompose total variance risk into systematic and idiosyncratic components, and conclude that both components command sizeable premiums and significantly affect option returns.

Driessen, Maenhout, and Vilkov (2009) use U.S. index and stock options prices to decompose the variance risk premium into idiosyncratic variance risk and correlation risk premium. They find that most of the documented variance risk premium of the U.S. index is due to correlation risk premium. Kelly et al. (2012) examine the price difference between 
index and individual options but focus on tail risk - the risk of extreme drops in stock pricesfor particular sectors. They find that the price difference between index and individual options is significant for most sectors, in line with the correlation risk premium evidence in Driessen et al. (2009). However, they find that, for the financial sector, index options that provide a hedge against downside risk are relatively cheaper than a basket of individual options with similar characteristics, which they interpret as evidence of a too-systemic-to-fail government bailout guarantee.

Although of a similar nature, the options-based risk measures in Driessen et al. (2009) and Kelly et al. (2012) differ in several important aspects. First, while the former is interested in measuring the correlation risk premium, that is, the difference between options-implied and expected correlation, the latter is mainly focused on the cost of insurance against common negative events, that is, the price difference between index options and individual options. Second, the measure in Kelly et al. (2012) gives more relevance to the downside risk by comparing only the prices of options that provide a hedge against large drops in the index or in individual stock prices. The measures in these two papers also consider different time-horizons. While Driessen et al. (2009) consider one-month ahead options, Kelly et al. (2012)'s benchmark measure considers one-year ahead options.

In our contribution to the correlation risk premium literature, we propose a measure of systemic risk that alters the correlation risk premium measure in Driessen et al. (2009), focusing on options that provide a hedge against downside risk, in line with the cost-ofinsurance measure in Kelly et al. (2012). In particular, our measure of DCRP uses prices of put options with 80 percent degree of moneyness, which provide a hedge against price drops of 20 percent or more in the next month, to calculate the options-implied downside variance for a bank index and for its individual components.

We investigate the effect of interventions on financial institutions on our DCRP measure, and highlight the differential effect of interventions on financial institutions in the U.S. and the euro area. Thus, we also contribute to a more general literature on the effect of central bank interventions. Beck, Coyle, Dewatripont, Freixas, and Seabright (2010) provide a summary of the broad goals of interventions. Laeven and Valencia (2010), Calderon and Kalus (2012), and Brei, Gambacorta, and von Peter (2011) among others, examine the positive and negative effects of bank interventions. Goodhart and Schoenmaker (2006) investigate an additional dimension for macroprudential policy in Europe, namely the cross-border externalities from bank failures. Posen and Veron (2009) and more recently Schoenmaker (2012) examine the lessons learned from the global and European crises for a banking union, including a single mechanism for the resolution of problems that allows for pan-European interventions. Interestingly, Schoenmaker (2012) includes examples of less successful crossborder interventions in the absence of an official banking union framework and how these interventions raised questions about how SIFIs should be handled in the euro area. Our paper is the first to show that interventions by euro-area member authorities are not successful in reducing systemic risk to the eyes of investors, except for those that involved several banks. In other words, we show that, even following interventions, agents are willing to pay to hedge the risk of correlated extreme drops in euro-area banks' equity prices. 


\section{Data and Methodology}

In the first part of this section, we introduce our measure of systemic risk, called downside correlation risk premium (DCRP). In the second part, we describe our novel dataset of U.S. and euro-area bank intervention announcements.

\subsection{The Downside Correlation Risk Premium}

Our measure of DCRP relies on the intuition that the variance of an index can be expressed as a function of the average variance of its components plus a combination of pairwise correlations. Following this relation, the variance risk premium of an index can be expressed as a combination of the average variance risk premium of its components plus a correlation risk premium component. More specifically, the variance risk premium of the bank index is defined as

$$
V R P_{t}^{\text {index }}=E_{t}^{Q}\left(\sigma_{r, t+1}^{2}\right)-E_{t}^{P}\left(\sigma_{r, t+1}^{2}\right)
$$

That is, it is the difference between the risk neutral $(Q)$ and the physical $(P)$ time- $t$ expectation of the index's return variation, $\sigma_{r, t+1}^{2}$, between dates $t$ and $t+1$ months. Following Driessen et al. (2009), equation (1) can be decomposed into

$$
V R P_{t}^{\text {index }}=\sum_{i} l_{i} V R P_{t}^{i}+\sum_{i} \sum_{j \neq i} \omega^{i} \omega^{j}\left[E_{t}^{Q}\left(\rho_{r_{t+1}{ }^{i} r_{t+1} j}\right)-E_{t}^{P}\left(\rho_{r, t+1^{i} r, t+1^{j}}\right)\right],
$$

where $V R P_{t}^{i}$ is the variance risk premium of the $i$-th component of the index, $\rho_{r_{t+1}{ }^{i} r_{t+1}{ }^{j}}$ is the correlation between the return of stock $i$ and that of stock $j$ over the period $t$ to $t+1$ months, and $l_{i}=\left(\omega^{i}\right)^{2}+\sum_{j \neq i} \omega^{i} \omega^{j} \frac{\sigma_{r_{j}}}{\sigma_{r i}} \rho_{r^{i} r^{j}}$ is the relative-volatility weight on each component's variance risk premium, assuming constant weights. $\sum_{i} \sum_{j \neq i} \omega^{i} \omega^{j}\left[E_{t}^{Q}\left(\rho_{r_{t+1}^{i} r_{t+1}^{j}}\right)-\right.$ $\left.E_{t}^{P}\left(\rho_{r_{t+1}^{i} r_{t+1}^{j}}\right)\right]$ is a collection of the correlation risk premiums between all individual components in the index, which we denote as $C R P_{t}^{\text {index }}$. Thus, equation (2) can be rewritten as

$$
C R P_{t}^{\text {index }}=V R P_{t}^{\text {index }}-\sum_{i \in \text { index }} l_{i} V R P_{t}^{i}
$$

The variance risk premium of the index can be interpreted as a measure of both idiosyncratic and systemic risk. Then, the correlation risk premium is the extra variance risk premium in the index that is not accounted for by its individual components, hence a risk-neutral measure of common system-wide risk. Our measure of downside correlation risk premium, DCRP, is constructed following equation (3), except it is calculated using 80 percent out-of-the-money (OTM) option prices, which provide a hedge against price drops of 20 percent or more.

We construct DCRP using the U.S. and euro-area benchmark bank indexes from Bloomberg (KBW and Eurostoxx, respectively) for a sample running from 2008 to 2013 at a daily frequency. For the duration of our sample, the Eurostoxx banks index includes banks for the following euro-area countries: Austria, Belgium, France, Germany, Greece, Italy, Ireland, the Netherlands, and Spain. Both indexes are calculated as a weighted average of the price

of major publicly-traded banks' stocks, and should serve therefore as a benchmark of the 
banking sector. Specifically, the KBW (Keefe, Bruyette \& Woods) index aggregates the price of the most relevant U.S. banks (approximately 24 institutions) weighted according to free-float market capitalization. The relevance of a bank is determined by KBW according to several criteria, including trading volume and market capitalization.1 The Eurostoxx banks index aggregates the price of the largest banks in the euro area (approximately 28 institutions), which are also weighted according to free-float market capitalization.2

To obtain our measure of DCRP, we calculate the variance risk premium components in equation (3) using equation (1). Specifically, to calculate the downside variance risk premium of each bank index as well as its components, we approximate the expectation of the return variation under the risk-neutral measure, $E_{t}^{Q}\left(\sigma_{r, t}^{2}\right)$, as the square of the implied-volatility of OTM put options. In particular, we use options with a fixed degree of moneyness of 80 percent for the index and its individual components. In section 4.4 , we investigate the robustness of our results using options with a degree of moneyness of 90 percent, which provide a hedge against a 10 percent or larger drop in the index's price. The options-implied volatility for the indexes and their components are obtained from Bloomberg. To reduce the potential adverse effect of outliers, especially for bank-specific options, we winsorize all options-implied volatilities at the 1 percent level.

We approximate the expectation of the bank index's return variation under the physical measure, $E_{t}^{P}\left(\sigma_{r, t}^{2}\right)$, using a forecast of the one-month ahead realized variance, conditional on the one-month-lagged index's implied-variance and the one-month-lagged realized variance itself. As is standard in the literature, we calculate the one-month realized variance as the sum of the square of daily stock returns for the last 22 days. Daily stock prices for the indexes and their components are also obtained from Bloomberg. More sophisticated approaches for calculating the realized volatility include high-frequency return-based measures of realized variance (Bollerslev, Tauchen, and Zhou, 2009). To avoid any look-ahead bias caused by using the full sample, we use only the information available at each point in time to calculate the expectation of the realized variance under the physical measure.

To calculate the physical expectation of the return variation for each individual bank within the index, we use each bank-specific implied variance, the lagged realized variance of the bank's stock return, and the options-implied variance of the bank index. We find that adding the options-implied variance of the bank index improves the forecast of all banks' one-month ahead realized variance considerably, compared to a model that includes either each bank's realized variance or both its realized and options-implied variance. For euro-area (U.S.) banks, the average adjusted R-squared when we forecast the one-month-ahead realized variance using only the realized variance is $0.45(0.48)$. When we include each bank's optionsimplied variance, the average adjusted R-squared increases to 0.46 (0.60), and when we add the bank index's implied variance, it increases to $0.50(0.62)$.

To calculate $l_{i}$, the relative-volatility weights in equation (3), we obtain estimates of the variance-covariance matrices of all banks within the bank indexes (and, implicitly, the correlations between them) as well as their relative market capitalizations, $\omega^{i}$. We estimate

\footnotetext{
${ }^{1}$ The rules for inclusion of a bank in the KBW index can be found at www.kbw.com/content/equitiesPDFs/IndexRules.pdf.

${ }^{2}$ The current components of the KBW index can be found at www.kbw.com/content/researchreports/BKX.pdf, and those of the Eurostoxx banks index can be found at www.stoxx.com/download/indexes/factsheets/estxsupersectorsfs.pdf.
} 
daily variance-covariance matrices using one-month (22-days) rolling windows of all banks' stock returns, and assume that their relative weights, calculated using each bank's market capitalization relative to the total market capitalization of the index, remain constant throughout this window. At each point in time, we use the one-day-lagged relative-volatility weights to obtain the weighted average downside variance risk premium, $\sum_{i \in i n d e x} l_{i} V R P_{t}^{i}$.

\subsection{Bank Interventions}

To examine the effect of central bank interventions on our options-based measure of risk, we use a unique dataset on bank intervention announcements. This dataset builds upon the "Financial Sector Rescue Plan" database maintained by the Bank of International Settlements (BIS). The BIS database was initiated in October 2008 under the auspices of the Committee on the Global Financial System (CGFS) and covers the following five main categories of financial sector support measures: capital injections (emergency loans, does not include immediate outright nationalization); deposit insurance; debt guarantees; asset relief measures (purchase or guarantee of risky non-performing bank assets); and credit market interventions. The BIS database includes all stand-alone actions and programs announced from September 2008 to December 2011 in 29 countries, including the U.S. and individual euro-area countries. Our dataset corrects the BIS database using Factiva and other news sources to make sure that the date of each intervention corresponds to the first time it was announced. Since the BIS database ends in 2011, we also extend the database to the end of 2013. In section 4.4, we perform robustness tests on the subsample period of the original BIS database from 2008-2011.

Using the intervention announcements database, we define a time-series dummy variable for government interventions on financial institutions for the U.S. and euro area separately. This variable takes the value of 1 on the days when new capital injections were announced and 0 otherwise. Since our measures of downside variance and correlation risk premiums are only defined over trading days, we match interventions that take place on a non-trading day to the next trading day. While the BIS database covers five categories of central bank interventions, we focus our analysis on capital injections, as they were at the core of most rescue packages and were critical for banks to withstand market pressures during the financial crisis (see, for instance, Brei et al. 2011). Other types of support either did not address solvency problems, such as deposit insurance and debt guarantees, or were deployed at very few institutions, such as asset purchases and insurance. Overall, our dataset contains 46 capital injection announcements in the U.S. and 106 announcements across individual euro-area countries from 2008-2013.

Our interventions dummy variable implicitly assumes that each intervention announcement was entirely received by the market as a surprise, which may not always be the case. To account for the unexpected component of each intervention announcement, we also construct an intervention surprise measure. This measure takes a value between 0 and 1 depending on the impact of the intervention announcement on the stock price of the specific bank being intervened. Specifically, the surprise measure is calculated as 1 minus the p-value that results from comparing the return of the bank stock in the day following the announcement with a normal distribution of daily returns for the full sample. If stocks of an intervened bank are not publicly traded, the intervention surprise measure is calculated based on the impact of the intervention announcement on the price of the bank index of the country where the bank 
is domiciled. If all intervention announcements had sizeable effects on the intervened banks' stock prices, the intervention surprise measure would converge to our interventions dummy variable.

In addition to examining the effect of intervention announcements on our measure of systemic risk, we also analyze which characteristics make certain interventions more or less successful in reducing DCRP. To do so, we construct the following seven conditional intervention dummy variables for the U.S. and the euro area:

1. Multiple country (defined for euro area only): equals 1 on days when capital injections were announced in more than one country in the euro area. The capital injections do not necessarily need to be part of the same general program.

2. Multiple bank: equals 1 on days where capital injections were announced for more than one bank (may or may not be in the same country).

3. Involved in stress test: equals 1 on days where capital injections were announced for banks that were involved in stress tests. For the U.S., we use the list of banks that were involved in Comprehensive Capital Analysis and Review (CCAR) 2012 $2^{3}$ For the euro area, we use the list of banks that were involved in the European Banking Authority's (EBA) 2011 EU-wide stress tests ${ }^{4}$

4. In banks index: equals 1 on days where capital injections were announced for banks that are in the KBW index for the U.S. and in the Eurostoxx banks index for the euro area.

5. Large bank: equals 1 on days where capital injections were announced for a bank with large market capitalization. A large bank is defined as having, on the day before the announcement, a market capitalization above the median value across all intervened banks in our sample. Data on market capitalization is from Bloomberg.

6. Large injection: equals 1 on days where a large capital injection for a bank was announced. A large capital injection is defined as having a ratio of injection size to bank total assets (on the day before the announcement) that is above the median value across all intervened banks in our sample. Data on injection size is from our interventions database and data on total assets is from Bloomberg.

7. Large SRisk: equals 1 on days where capital injections were announced for a bank with a large SRisk value. A large SRisk is defined as having, on the day before the announcement, a value above the median value across all intervened banks in our sample. SRisk is a measure of systemic risk proposed by Brownless and Engle (2012), which depends on each bank's leverage, size, and Marginal Expected Shortfall (MES). MES is calculated as the expected loss in the total value of a firm in the event of a substantial decline in the market, which is approximated by the S\&P 500 .

\footnotetext{
${ }^{3}$ See http://www.federalreserve.gov/newsevents/press/bcreg/bcreg20120313a1.pdf.

${ }^{4}$ See http://www.eba.europa.eu/risk-analysis-and-data/eu-wide-stress-testing/2011/results.
} 
Finally, to disentangle the effect of bank interventions from the effect of other macroeconomic announcements that might have an impact on our options-based risk measures, we control for the surprise in macroeconomic news announcements in the U.S. and Europe. We use daily data on real-time activity indexes from Scotti (2013). The surprise indexes in Scotti (2013) are constructed as the weighted average of the surprises from the set of macroeconomic releases in Aruoba, Diebold, and Scotti (2009). These macroeconomic releases include industrial production, employment, real retail sales, personal income, manufacturing PMI, the slope of the yield curve, and stock market returns.

\section{Effect of Bank Interventions on Options-based Risk Measures}

In this section, we examine the differences between the DCRP in the U.S. and the euro area, and investigate the effect of government intervention announcements on our options-based risk measures.

\subsection{DCRP in the U.S. and the Euro Area}

Figure 1 displays our measure of DCRP for the U.S. and euro-area bank indexes. Table 1 reports the summary statistics for the DCRP and its components (see equation (3)). Figure 2 plots the two components of DCRP: the bank index's downside variance risk premium and the relative-volatility-weighted average of the downside variance risk premium of all banks within the index.

Individual options for banks in the U.S. KBW index are on average more expensive than index options. In particular, as shown in Table 1, the implied volatility of individual banks' OTM options is higher than that of the index options (48 percent versus 39 percent). In addition, the relative-volatility-weighted average of the downside variance risk premiums of the index's individual components is significantly higher than the downside variance risk premium of the bank index (255 versus -33). This difference holds irrespective of the weights assigned to individual banks' variance risk premiums in equation (3). As a consequence, the DCRP for U.S. banks is on average negative and significant. In fact, the U.S. DCRP is particularly negative around the Lehman Brothers episode (Figure 1), where the largest U.S. bank interventions take place in our sample. This evidence might appear counterintuitive, as agents should demand a positive compensation for their exposure to time-varying correlation risk among the banks in the index. However, the average negative premium and the negative DCRP peak around the Lehman Brothers episode is in line with the evidence in Kelly et al. (2012). They show that around the 2008 U.S. bank interventions, the cost of insurance against extreme events for individual banks increased in comparison to the cost of insurance for the U.S. bank index.

The difference between the cost of insurance of the index and its components suggests that agents believe a simultaneous drop in the price of all bank stocks is less likely to occur, as authorities demonstrate they are willing to prevent a collapse of the banking system by intervening in systemically important banks. Similarly, we observe in panel (a) of Figure 2 that after the bulk of the 2008 bank interventions, the downside variance risk premium of both the bank index and individual banks dropped significantly, but dropped less for individual 
banks; that is, the OTM options-implied volatility is lower than expected realized volatility. This pattern is consistent with the view that agents became less concerned about overall volatility risk in light of the government interventions, but relatively less concerned about the bank index's downside variance risk than about individual banks' downside variance risk.

In contrast to the evidence for the U.S., as shown in panel (b) of Table 1 , the downside variance risk premium of the euro-area bank index is on average larger than the relativevolatility-weighted average of the downside variance risk premiums of its individual components (1074 versus 780). Thus, the DCRP for euro-area banks - the extra downside variance risk premium in the bank index that is not accounted for by its individual components - is on average positive (294) and significant at the 1 percent level. This evidence suggests that agents are willing to pay a premium to hedge downside systemic risk in the euro-area banking system.

The euro-area DCRP is particularly large in the second half of 2011, at the peak of the European debt crisis. As can be seen in panel (b) of Figure 2, during this period the downside variance risk premium of the euro-area bank index increases much more than the average downside variance risk premium of the index components. In fact, most of the spikes in DCRP are closely linked to crisis-related news, especially in the last quarter of 2011. Between September and December of 2011, concerns about economic growth in the euro area added to concerns about Greece's inability to meet its budget cut targets and the country's increasing needs of bailout loans. Other episodes of the European debt crisis had an impact on the DCRP, such as Spain's intentions to seek financial support for the country's banks between June and August 2012. However, not all DCRP spikes are closely related to news and might be affected by other factors, such as option pricing errors. In an event study around DCRP spikes to disentangle news-related spikes from outliers, we find that a 1 percent winsorization provides a good balance between excluding most of the outliers without excluding important news-related episodes of high DCRP.

Interestingly, the DCRP for U.S. banks often increases around news in the euro area that deteriorated overall risk sentiment. For instance, the U.S. DCRP spiked on November 2010 as markets grew concerned about Ireland's banking sector. Also, by the end of September 2011, stock markets worldwide fell significantly in reaction to weaker-than-expected euro-area economic data. Concerns about the crisis in Europe increased again at the beginning of October 2011 as European finance ministers began discussing plans to recapitalize the region's financial institutions.

\subsection{Options-based Systemic Risk}

Our preliminary evidence suggests that while euro-area DCRP is closely related to episodes of high economic uncertainty, U.S. DCRP appears at times to be a counterintuitive measure of systemic risk. In particular, U.S. DCRP is largely negative around the global financial crisis, when although economic uncertainty was large, several bank interventions seem to have had a considerable impact on systemic risk to the eyes of investors.

A desired characteristic of systemic risk measures is for them to be useful predictors of distress in the economy. To formally investigate the relation between DCRP and economic distress, we follow Brownless and Engle (2012) and model the vector autoregression (VAR) 
process

$$
y_{t}=\sum_{l=1}^{p} A_{j} y_{t-l}+\epsilon_{t}
$$

where

$$
y_{t}=\left[\begin{array}{c}
\% \Delta\left(D C R P_{t}\right) \\
\Delta \log \left(I N D P R D_{t}\right) \\
\Delta \log \left(U R A T E_{t}\right)
\end{array}\right]
$$

is a vector consisting of the monthly growth rates of DCRP, industrial production, and unemployment rate. Since DCRP can be negative, instead of taking the log change, we compute the percent change in month $t$ as $100 * \frac{\left(D C R P_{t}-D C R P_{t-1}\right)}{\left|D C R P_{t-1}\right|}$. As in Brownless and Engle (2012), we assume that the order of the VAR process is one as increasing the number of lags does not change the significance but comes at the cost of an increasing number of parameters.

Table 2 shows the level and significance of the coefficients in equation (4). U.S. DCRP is not caused by either INDPRD or URATE. Thus, DCRP is not merely picking up real economy effects. At the same time, U.S. DCRP does not Granger cause the real variables. This is consistent with our view that DCRP is not necessarily a direct measure of systemic risk but rather a risk-neutral measure of systemic risk. And, as we documented in section 4.1, agents in the U.S. appear to be less concerned about a simultaneous drop in the price of all bank stocks, as authorities demonstrated that they are willing to prevent a collapse of the banking system by intervening in SIFIs.

For the euro area, DCRP is also not caused by either INDPRD or URATE. But, in contrast to the results for the U.S., euro-area DCRP Granger causes euro-area INDPRD. The economic magnitude of the causality between DCRP and INDPRD is considerable - a one standard deviation increase in euro-area DCRP decreases the region's industrial production by 12 basis points in the next month and is significant at the 5 percent level. While DCRP does not directly Granger cause URATE, INDPRD does Granger cause it. This indicates that DCRP will indirectly impact unemployment rate via its effect on industrial production.

In the remainder of this section, we provide an explanation for the differences in the dynamics and informational content between U.S. and euro-area DCRP. In particular, we show that bank intervention announcements in the U.S. have a significant and economically meaningful effect in reducing the DCRP, while interventions by euro-area authorities seem to have been unsuccessful in reducing DCRP. In the following section, we also show that interventions by U.S. authorities are successful, irrespective of their characteristics, while for the euro area, only interventions that involved multiple banks have a significant effect at reducing the DCRP.

\subsection{Effect of Bank Intervention Announcements}

The empirical framework we use to examine the effect of the announcement of government interventions on our banks' options-based risk premium measures is

$$
r p_{i, t+h}=c_{i, h} D_{i, t}+s_{i, h} \operatorname{Surp}_{i, t}+\epsilon_{t, h},
$$


where $r p_{i, t+h}$ is one of the following $h$-days ahead options-based risk measures for country/region $i$ : (a) the DCRP of the bank index, (b) the downside variance risk premium of the bank index, and (c) the relative-volatility-weighted average of downside variance risk premiums of individual banks in the index. Dummy $D_{i, t}$ is equal to 1 if there is a capital injection intervention announcement in country $i$ at time $t$ and $\operatorname{Surp}_{i, t}$ is Scotti (2013)'s macroeconomic surprise index.

Figure 3 reports the U.S. regression results for equation $(6)$ for $h=1$ to 30 days after a capital injection announcement. Panel (a) reports the coefficient of government intervention announcements on the DCRP and panels (b) and (c) report the effect on the downside variance risk premium of the index and on the average downside variance risk premiums of all individual banks within the index, respectively. The results suggest that bank interventions in the U.S. have a significant effect on downside correlation risk to the eyes of investors. Specifically, announcements of government interventions in the U.S. reduce banks' DCRP by approximately 950 squared percentage points one day after the injection announcement, and this effect remains significant for nearly all 30 days in our horizon window. As pointed out above, the significance of government interventions might explain the highly negative DCRP around the Lehman Brothers episode in Figure 1. The results in panels (b) and (c) show that intervention announcements are also significant at reducing both components of DCRP, where announcements have a larger impact on the U.S. bank index's downside variance risk premium, a measure of aggregate risk, than on the average downside variance risk premium of its components, a measure of bank-specific risk.

Our results for the euro area in Figure 4 stand in sharp contrast to those for the U.S. Notably, announcements of bank interventions by euro-area authorities do not have a significant effect on the DCRP among euro-area banks. The insignificant effect of these interventions might explain the average positive DCRP among euro-area banks, particularly during the latter half of 2011, as seen in Figure 1. The results in panels (b) and (c) of Figure 4 help us understand the lack of significance of bank interventions on the euro-area DCRP. In particular, intervention announcements in the euro area do significantly reduce both the index's downside variance risk premium and the average downside variance risk premiums of its components, but the effect is similar in magnitude across these two components. In addition, we note that the impact of intervention announcements on the index's downside variance risk premium is only about half the magnitude in the euro area as it is in the U.S.

Until now, we have assumed in our regressions that announcements of capital injections have similar characteristics and are a complete surprise to the market, with all of the changes in DCRP being attributed to our dummy variable on intervention announcements (after controlling for macroeconomic surprises). Given that certain intervention announcements may have come as more of a surprise than others, we construct an alternative to our dummy variable, $P_{i, t}$, which takes a value between 0 and 1 for an announcement in country $i$ at time t. $P_{i, t}$, our p-value intervention variable, represents the likelihood that the capital injection announcement was a surprise to the market. Construction of $P_{i, t}$ is described in section 3.2 . Our new regression framework is then

$$
r p_{i, t+h}=c_{i, h} P_{i, t}+s_{i, h} \operatorname{Surp}_{i, t}+\epsilon_{t, h} .
$$

As shown in Figure 5 , accounting for the surprise component of intervention announcements does not alter our primary findings for the U.S. and the euro area, in Figures 3 and 4 . 
respectively. In particular, capital injection surprises still reduce U.S. banks' DCRP (panel (a)). Interestingly, the estimated effect of intervention surprises by U.S. authorities is considerably larger than the effect of the intervention dummy (1600 versus 950 squared percentage points) and is significant for all 30 days in our horizon window. For the euro area, accounting for capital injection surprises still does not significantly reduce euro-area banks' DCRP (panel (b)).

In sum, our results show that agents do demand a significant premium to hedge downside correlation risk among banks in the euro area. Our results also show that interventions by euro-area authorities do not significantly reduce this DCRP, as these interventions do not have a sufficiently large differential effect on the downside variance risk premium of the index and its components. The results for the euro area stand in sharp contrast to those for the U.S., where the DCRP is on average negative, and interventions do have a significant and economically meaningful alleviating effect.

\subsection{Robustness Tests}

In this section, we show that our benchmark results in section 4.3 are robust to the sample period considered, liquidity and informational-content concerns of options, and to different magnitudes of downside events (degrees of options moneyness considered). In unreported results, we also confirm that our results are robust to considering all five categories of central bank interventions: capital injections, deposit insurance, debt guarantees, asset relief measures, and credit market interventions.

Our full sample period runs from 2008 to 2013. Because the original BIS database ends in 2011 and because most bank intervention announcements occurred by the end of 2011, we repeat the regression in equation (6) for the 2008-2011 subsample period. The results are consistent with those for our full sample period. Specifically, intervention announcements in the U.S. significantly reduce our options-based measure of systemic risk for nearly all 30 days after the announcement (Figure 6 panel (a)), while announcements in the euro area are ineffective at alleviating DCRP (Figure 7 panel (a)).

We also address two common concerns when dealing with options, especially at the firm-level: their liquidity and informational content. As a robustness test, we only include the 10 largest banks in each bank index in calculating our options-based risk measures, as large banks are less likely to be subject to these concerns. As of December 2013, the 10 largest banks account for 86 and 76 percent of the total market capitalization of all banks in the U.S. KBW and the euro-area Eurostoxx bank index, respectively. Results in panel (b) of Figure 6 show that bank intervention announcements still have a significant alleviating effect on the DCRP of the largest U.S. banks. Panel (b) of Figure 7 presents the corresponding results for the largest euro-area banks. Consistent with our benchmark results in Figure 4 , intervention announcements in the euro area do not significantly reduce DCRP.

Finally, we test whether our results hold for alternative magnitudes of downside risk events. Our benchmark measure of DCRP is calculated based on options with 80 percent degree of moneyness. Because these options provide a hedge against downside risk, DCRP measures the compensation agents demand for price drops of 20 percent or more in the bank index as well as in the individual banks in the index. We acknowledge, however, that a price drop of 20 percent for the index might be a much more drastic event than a price drop of the same magnitude for an individual bank. Thus, we examine whether our results still hold 
under a scenario where the hedge in the price drop for the bank index is less than the hedge in the price drop for its components. In particular, panel (c) in Figures 6 and 7 show the coefficients associated with our dummy intervention variable, where DCRP is calculated using options prices with 90 percent degree of moneyness for the bank index (thus a hedge against price drops of 10 percent or more) and 80 percent degree of moneyness for individual banks in the index. For the U.S., intervention announcements still reduce DCRP, although the magnitude and significance are much higher than for our benchmark results. The results for the euro area still indicate that intervention announcements do not alleviate DCRP; in fact, the coefficient is weakly positive for some horizons.

\section{Characteristics of Bank Interventions}

Our results so far suggest that there are significant differences between the results for the U.S. and those for the euro area. In particular, we find that intervention announcements in the U.S. are successful in reducing the DCRP to the point that this risk-neutral measure of systemic risk is on average negative, especially around the Lehman Brothers' episode. However, interventions by euro-area authorities do not have a significant effect on the region's DCRP. As a result, the euro-area DCRP is, on average, positive and displays considerable spikes, especially around the peak of the European debt crisis. In this section, we extend our investigation to understand the characteristics of successful interventions. In the first part of the section, we use the conditional intervention dummies described in section 3.2 to understand which intervention characteristics are more effective at alleviating DCRP. In the second part, we center the attention on the euro area, and explore the effect of country-specific interventions.

\subsection{Characteristics of Successful Interventions}

To examine the effect of intervention announcements with particular charateristics on the DCRP, we propose two regression frameworks. The first framework is the following univariate (with control variables) regression setup:

$$
\operatorname{DCRP} P_{i, t+h}=\beta_{c, i, h} D_{i, t}^{c}+s_{i, h} \operatorname{Surp}_{i, t}+\epsilon_{t, h},
$$

where $D_{i, t}^{c}$ is one of the seven conditional intervention dummies defined in section 3.2 and only takes a value conditional on days when capital injections are announced. The second framework is a multivariate (with control variables) regression setup that allows us to isolate the additional effect of each type of intervention announcement,

$$
\operatorname{DCRP}_{i, t+h}=\beta_{c, i, h}^{*} D_{i, t}^{c}+\beta_{i n t, i, h}^{*} D_{i, t}+s_{i, h} \operatorname{Surp}_{i, t}+\epsilon_{t, h}
$$

where $D_{i, t}$ is the intervention dummy used for the benchmark results in section 4.3 .

Table 3 reports the estimated effect, $\beta_{c}$, and the additional effect, $\beta_{c}^{*}$, of intervention announcements with particular characteristics. Our results for the U.S. show that intervention announcements have a negative and significant effect on the DCRP across all seven characteristics we condition on $\left(\beta_{c}\right)$. However, the magnitude of the estimated effect is much larger for interventions that involved more than one bank $\left(\widehat{\beta}_{c}=-1747\right)$, interventions to 
banks involved in the Federal Reserve's stress test $\left(\widehat{\beta}_{c}=-1680\right)$, and interventions to banks in the U.S. KBW bank index $\left(\widehat{\beta}_{c}=-1339\right)$. In fact, the results show that interventions to banks involved in the stress test or to one of the banks in the bank index have an additional relieving effect on the DCRP across U.S. banks - $\beta_{c}^{*}$ is negative and significant. Surprisingly, there is a disconnect between the definition of SIFIs according to the stress test and that according to SRisk, as interventions to banks with relatively large SRisk do not have a significant additional alleviating effect $-\beta_{c}^{*}$ is insignificant.

In contrast, the results for the euro area suggest that only interventions that involved multiple banks are somewhat successful in alleviating the DCRP $\left(\widehat{\beta}_{c}=-558\right.$ and significant at the 10 percent confidence level). All other types of interventions have an insignificant effect (and additional effect) on the DCRP.

\subsection{Country-specific Bank Interventions in the Euro Area}

To shed further light on our empirical results for the euro area, we examine the differential effects of country-specific bank interventions. Our results allow us to identify particular countries within the euro area whose capital injection announcements have a greater effect on reducing the region's DCRP. Furthermore, decomposing the euro-area intervention dummy into country-specific dummies allows us to disentangle country-specific effects, as multiple announcements for different countries often occur on the same day.

The regression framework to examine the joint effect of country-specific bank interventions on the DCRP in the euro area is

$$
D C R P_{t+h}^{\text {euro }}=\sum_{i} c_{i, h} D_{i, t}+s_{\text {euro }, h} \operatorname{Surp}_{\text {euro }, t}+\epsilon_{t, h},
$$

where we decompose the euro-area capital injection dummy in equation (6) into 8 countries/regions: Belgium, France, Germany, Greece, Italy, Netherlands, Spain, and the rest of the euro area.

Figure 8 plots the estimated coefficients, $c_{i, h}$, for $h=1$ to 30 days after a capital injection announcement. Our results suggest that, in general, interventions by euro-area member countries do not have an economically meaningful effect on the DCRP. French interventions (panel (b)) are weakly significant in reducing the euro-area DCRP up to 4 days after an intervention. Italian and Dutch bank interventions are only significant 13 and 5 days after an intervention, and the effect is short-lived (panels (e) and (f)). For the remaining countries, the results indicate that country-specific interventions do not reduce DCRP for euro-area banks, in line with our results in Figure 4. We also note that the coefficients from regressing on each country-specific intervention dummy separately are essentially the same as the coefficients from the joint regression with all country

In unreported results, we find that, for most countries, bank interventions do seem to have an effect on the average downside variance risk premium of individual banks, but this effect is economically meaningful only for banks within the country intervening. The disparity between results for local and foreign average downside variance risk premiums suggests that investors believe there are cross-border differences in banks' interventions across the euro area. These results serve as preliminary evidence that agents do not perceive the euro area as having a unified banking system. 
In sum, our results suggest that interventions by U.S. authorities have a significant alleviating effect on our options-based measure of systemic risk, irrespective of their characteristics. In particular, interventions to U.S. banks in the KBW bank index or to banks involved in the Federal Reserve's stress tests have an additional relieving effect on DCRP in the banking sector. This evidence suggests that interventions by U.S. authorities appear credible to investors, as they reduce systemic risk to the eyes investors. However, for the euro area, only intervention announcements that involved multiple banks were marginally successful in reducing the region's DCRP. All other types of interventions, including country-specific intervention announcements, have an insignificant effect on the DCRP, often with the opposite sign. Our evidence suggests that the lack of success of intervention announcements by euro-area authorities is, in part, due to a segmented view of the financial system, where interventions only appear to have an effect on country-specific risk.

\section{Conclusion}

In this paper, we propose a measure of downside correlation risk premium (DCRP) to investigate the effect of central bank interventions on systemic risk. Our measure of DCRP is calculated as the difference between the downside variance risk premium of the major bank index and the weighted average of the downside variance risk premiums of individual banks within the index. We show that there are significant differences in the unconditional level of DCRP in the U.S. and euro-area banking sector. In particular, DCRP is on average negative for banks in the U.S. and positive, especially around key episodes of the European debt crisis, for euro-area banks. This evidence suggests that investors are willing to buy protection against the risk that banks in the euro area experience simultaneous large drops in stock prices. We hypothesize that the main driver of this difference in the unconditional level of DCRP is investors' perception of how effective central bank interventions are in reducing systemic risk.

Exploiting a novel dataset on central bank interventions, we find that irrespective of their characteristics, intervention announcements by U.S. authorities are successful in reducing DCRP. In contrast, intervention announcements by euro-area authorities have an insignificant effect on DCRP, except for those involving several banks. We also document evidence that investors view interventions in euro-area countries as segmented, where interventions are only successful in reducing the average downside variance risk premium of banks domiciled in the country of intervention, but not of banks domiciled outside of the country. However, these country-specific interventions are unsuccessful in reducing DCRP for the region as a whole. 


\section{References}

Acharya, V., L. Pedersen, T. Philippon, and M. Richardson (2010, May). Measuring systemic risk.

Adrian, T. and M. Brunnermeier (2011). Covar. working paper Federal Reserve Bank of New York.

Aruoba, S. B., F. X. Diebold, and C. Scotti (2009). Real-Time Measurement of Business Conditions. Journal of Business and Economic Statistics 27(4), 417-427.

Bakshi, G. and N. Kapadia (2003). Volatility risk premum embedded in individual equity options: some new insights. Journal of Derivatives, 45-54.

Bakshi, G. and D. Madan (2006, December). A theory of volatility spreads. Management Science 52(12), 1945-1956.

Beck, T., D. Coyle, M. Dewatripont, X. Freixas, and P. Seabright (2010). Bailing out banks: Reconciling stability and competition. mimeo, CEPR.

Bekaert, E. and E. Engstrom (2009). Asset return dynamics under bad environment good environment fundamentals. NBER Working Paper 15222.

Bisias, D., M. Flood, A. Lo, and S. Valavanis (2012, January). A survey of systemic risk analytics. Office of Financial Research Working Paper 0001.

Bollerslev, T., M. Gibson, and H. Zhou (2011, January). Dynamic estimation of volatility risk premia and investor risk aversion from option-implied and realized volatilities. Journal of Econometrics 160(1), 235-245.

Bollerslev, T., G. Tauchen, and H. Zhou (2009). Expected stock returns and variance risk premia. Review of Financial Studies 22, 4463-4492.

Brandt, O. D. and P. Hartmann (2000). Systemic risk: a survey. ECB working paper No. 35.

Brei, M., L. Gambacorta, and G. von Peter (2011). Rescue packages and bank lending. BIS working paper No. 357.

Britten-Jones, M. and A. Neuberger (2000). Option prices, implied price processes, and stochastic volatility. Journal of Finance 55(2), 839-866.

Brownless, C. T. and R. Engle (2012). Volatility, correlation and tails for systemic risk measurement. working paper Universitat Pompeu Fabra and New York University.

Calderon, C. and S. Kalus (2012). Bank bailouts, competitive distortions, and consumer welfare. mimeo, World Bank.

Carr, P. and L. Wu (2009, March). Variance Risk Premiums. Review of Financial Studies 22(3), 1311-1341. 
Driessen, J., P. J. Maenhout, and G. Vilkov (2009, June). The Price of Correlation Risk: Evidence from Equity Options. Journal of Finance 64(3), 1377-1406.

Duan, J.-C. and J. Wei (2009). Systematic risk and the price structure of individual equity options. Review of Financial Studies 22 (5), 1981-2006.

Gabaix, X. (2012, May). Variable Rare Disasters: An Exactly Solved Framework for Ten Puzzles in Macro-Finance. Quarterly Journal of Economics 127(2), 645-700.

Goodhart, C. and D. Schoenmaker (2006). Burden sharing in a banking crisis in Europe. Sveriges Riksbank Economic Review 2, 34-57.

Huang, X., H. Zhou, and H. Zhu (2009). A framework for assessing the systemic risk of major financial institutions. Journal of Financial Economics 33, 2036-2049.

Huang, X., H. Zhou, and H. Zhu (2012). Systemic risk contributions. Journal of Financial Services Research 42, 55-83.

Jiang, G. and Y. Tian (2005). The model-free implied volatility and its information content. Review of Financial Studies 18(4), 1305-1342.

Kelly, B. T., H. N. Lustig, and S. V. Nieuwerburgh (2012, March). Too-systemic-to-fail: What option markets imply about sector-wide government guarantees. Working Paper, Chicago Booth School of Business.

Laeven, L. and F. Valencia (2010). Resolution of banking crises: The good, the bad, and the ugly. mimeo, IMF.

Londono, J. M. (2011, September). The variance risk premium around the world.

Newey, W. K. and K. D. West (1987). A simple, positive semi-definite heteroskedasticity and autocorrelation consistent covariance matrix. Econometrica 55 (3), 703-708.

Posen, A. and N. Veron (2009). A solution for europe's banking problem. mimeo, Peterson Institute for International Economics.

Schoenmaker (2012). Banking supervision and resolution: The european dimension. mimeo, Duisenberg School of Finance.

Schurhoff, N. and A. Ziegler (2011, February). Variance risk, financial intermediation, and the cross-section of expected option returns.

Scotti, C. (2013). Surprise and uncertainty indexes: Real-time aggregation of real-activity macro surprises. mimeo, Federal Reserve Board.

Todorov, V. (2010, January). Variance Risk-Premium Dynamics: The Role of Jumps. Review of Financial Studies 23(1), 345-383. 


\section{Tables and Figures}

\section{Table 1: Variance and correlation risk premiums, summary statistics}

This table reports the summary statistics for several options-based risk measures for the U.S. and euro-area bank indexes. Columns 1 and 2 report the options-implied volatility of the bank index and the equal-weighted average (EW) average of the implied volatility of individual banks in the index, respectively. Implied volatility is calculated using 80 percent degree of moneyness options. Columns 3 and 4 report the downside variance risk premium of the bank index and the relative-volatility-weighted (VW) average of the downside variance risk premium of individual banks in the index, respectively. Downside variance risk premium is calculated as the difference between the (80 percent moneyness) options-implied variance and the expected realized variance, as described in section 3.1. The last column reports the downside correlation risk premium (DCRP), which is calculated as the difference between columns 3 and 4 (see equation(3p). Units for implied volatility are in percentage points while units for variance and correlation risk premium are in percentage squared points. $* * *$ indicates significance at the 1 percent level.

Panel (a) U.S. bank index (KBW)

\begin{tabular}{l|ll|ll|l}
\hline & \multicolumn{1}{|c|}{$(1)$} & \multicolumn{2}{c|}{$(2)$} & $(3)$ & \multicolumn{1}{c}{$(5)$} \\
\hline & \multicolumn{2}{|c|}{ Implied volatility } & \multicolumn{2}{c}{ Variance risk premium } & \multirow{2}{*}{ DCRP } \\
\cline { 2 - 5 } & Index & Banks (EW) & Index & Banks (VW) & \multicolumn{1}{c}{ DCR } \\
\hline Mean & 38.8 & 48.3 & -32.7 & $254.6^{* * *}$ & $-287.3^{* * *}$ \\
Median & 32.7 & 41.6 & 271.7 & 466.8 & -117.9 \\
St. Dev. & 22.1 & 27.6 & $1,336.1$ & $1,068.0$ & 720.8 \\
Skew. & 1.4 & 1.7 & -4.1 & -3.5 & -3.6 \\
Kurt. & 4.8 & 5.7 & 28.7 & 19.5 & 28.4 \\
\hline
\end{tabular}

Panel (b) Euro-area bank index (Eurostoxx)

\begin{tabular}{l|ll|ll|l}
\hline & \multicolumn{2}{|c|}{ Implied volatility } & \multicolumn{2}{c|}{ Variance risk premium } & \multirow{2}{*}{ DCRP } \\
\cline { 2 - 5 } & Index & Banks $(\mathrm{EW})$ & Index & Banks $(\mathrm{VW})$ & DC \\
\hline Mean & 51.9 & 61.7 & $1074.3^{* * *}$ & $780.1^{* * *}$ & $294.2^{* * *}$ \\
Median & 48.9 & 60.1 & 976.0 & 768.7 & 231.3 \\
St. Dev. & 13.2 & 13.9 & $1,341.5$ & $1,362.8$ & 904.7 \\
Skew. & 0.9 & 0.6 & -1.4 & -6.4 & 2.1 \\
Kurt. & 3.2 & 2.8 & 16.3 & 60.6 & 17.3 \\
\hline
\end{tabular}




\section{Table 2: DCRP and economic distress}

This table shows the level and significance of the coefficients in the following VAR process:

$$
y_{t}=A_{1} y_{t-1}+\epsilon_{t},
$$

where $y_{t}$ consists of the monthly growth rates of DCRP(downside correlation risk premium), INDPRD (industrial production), and URATE (unemployment rate). The rows indicate the variable that is caused by the variables in the columns. For instance, row INDPRD and column DCRP reports the coefficient and statistical significance for DCRP being caused by INDPRD. Reported coefficients are the effect in each column of a one standard deviation shock in the series in each row. ${ }^{* *},{ }^{* *}$, and ${ }^{*}$ denote significance at the 1,5 , and 10 percent level respectively.

\begin{tabular}{|c|c|c|c|c|c|c|}
\hline \multirow{4}{*}{$\begin{array}{l}\text { DCRP } \\
\text { INDPRD }\end{array}$} & \multicolumn{3}{|c|}{ U.S. } & \multicolumn{3}{|c|}{ Euro Area } \\
\hline & DCRP & INDPRD & URATE & DCRP & INDPRD & URATE \\
\hline & & 75.02 & 98.75 & & -95.48 & -13.32 \\
\hline & 0.01 & & $-0.18^{* * *}$ & $-0.12^{* *}$ & & $-0.19 * * *$ \\
\hline URATE & 0.12 & $-0.43^{* * *}$ & & -0.02 & $-0.25 * * *$ & \\
\hline
\end{tabular}




\section{Table 3: The effect of characteristics of intervention announcements on DCRP}

This table shows the coefficients from the following regression setups:

$$
\operatorname{DCRP}_{i, t+h}=\beta_{c, i, h} D_{i, t}^{c}+s_{i, h} \operatorname{Surp}_{i, t}+\epsilon_{t, h}
$$

and

$$
\operatorname{DCRP}_{i, t+h}=\beta_{c, i, h}^{*} D_{i, t}^{c}+\beta_{i n t, i, h}^{*} D_{i, t}+s_{i, h} \operatorname{Surp}_{i, t}+\epsilon_{t, h},
$$

where DCRP is the downside correlation risk premium for the U.S. or the euro area. Dummy $D_{t}^{c}$ is one of the following types of interventions defined in section 3.2. (1) involving multiple countries (defined only for the euro area), (2) involving multiple banks, (3) to banks involved in stress tests, (4) to one of the banks in the benchmark bank index, (5) to relatively large banks, (6) relatively large capital injections, or (7) relatively

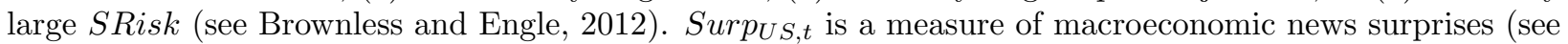
Scotti, 2013). Standard errors are corrected using Newey and West (1987) with 10 lags. We report only the coefficient for the day following the intervention announcement, $h=1$.

\begin{tabular}{l|lll|lll}
\hline \multirow{2}{*}{ Type of intervention } & \multicolumn{3}{|c|}{ U.S. } & \multicolumn{3}{c}{ Euro Area } \\
\cline { 2 - 7 } & $\beta_{c}$ & $\beta_{c}^{*}$ & $\beta_{\text {int }}{ }^{*}$ & $\beta_{c}$ & $\beta_{c}^{*}$ & $\beta_{\text {int }}{ }^{*}$ \\
\hline Multiple country & & & & -377 & -303 & -79 \\
Multiple bank & $-1747^{*}$ & -1118 & $-657^{* * *}$ & $-558^{*}$ & -743 & 192 \\
Involved in stress test & $-1680^{* *}$ & $-1190^{*}$ & $-505^{* *}$ & -131 & -51 & -82 \\
In banks index & $-1339^{* *}$ & $-1098^{*}$ & -243 & 202 & 467 & -278 \\
Large bank & $-1069^{*}$ & -275 & $-814^{* * *}$ & 885 & 1257 & $-394^{* *}$ \\
Large injection & $-963^{* *}$ & -69 & $-919^{* *}$ & 590 & $994^{*}$ & $-422^{*}$ \\
Large SRisk & $-1143^{* *}$ & -456 & $-704^{* * *}$ & 714 & 1179 & $-489^{* *}$ \\
\hline
\end{tabular}


Figure 1: U.S. and euro-area DCRP

The figure plots the downside correlation risk premium (DCRP) for the euro area (the bold line) and the U.S. (the dashed line) from 2008-2013. DCRP is computed as the difference between the downside variance risk premium of the bank index and the relative-volatility-weighted average of the downside variance risk premiums of its individual components (see equation (3p). The downside variance risk premium is calculated as the difference between the OTM options-implied and the expected realized variance. The options-implied variance is calculated using options with 80 percent degree of moneyness.

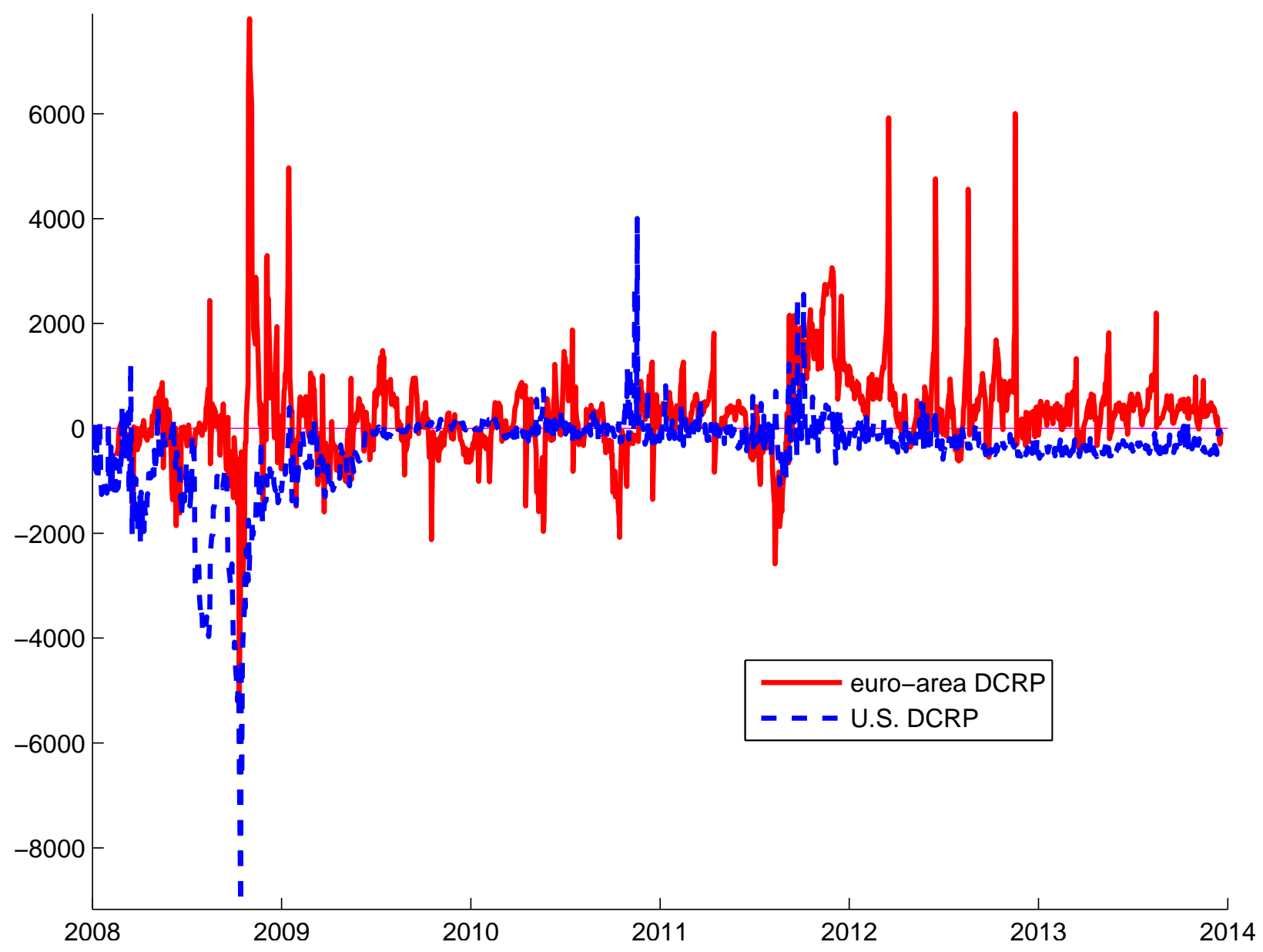


Figure 2: DCRP components

The figure plots the components of the downside correlation risk premium (DCRP) for the U.S. and the euro area in panels (a) and (b), respectively. The components are the downside variance risk premium (VRP) of each region's bank index (dotted line) and the relative-volatility-weighted average of the downside variance risk premiums of individual banks in the bank index (solid line). DCRP is defined as the difference between the dotted and solid lines (see equation 3). We also plot the timing of capital injection announcements in each region (the vertical bars).

(a) U.S.

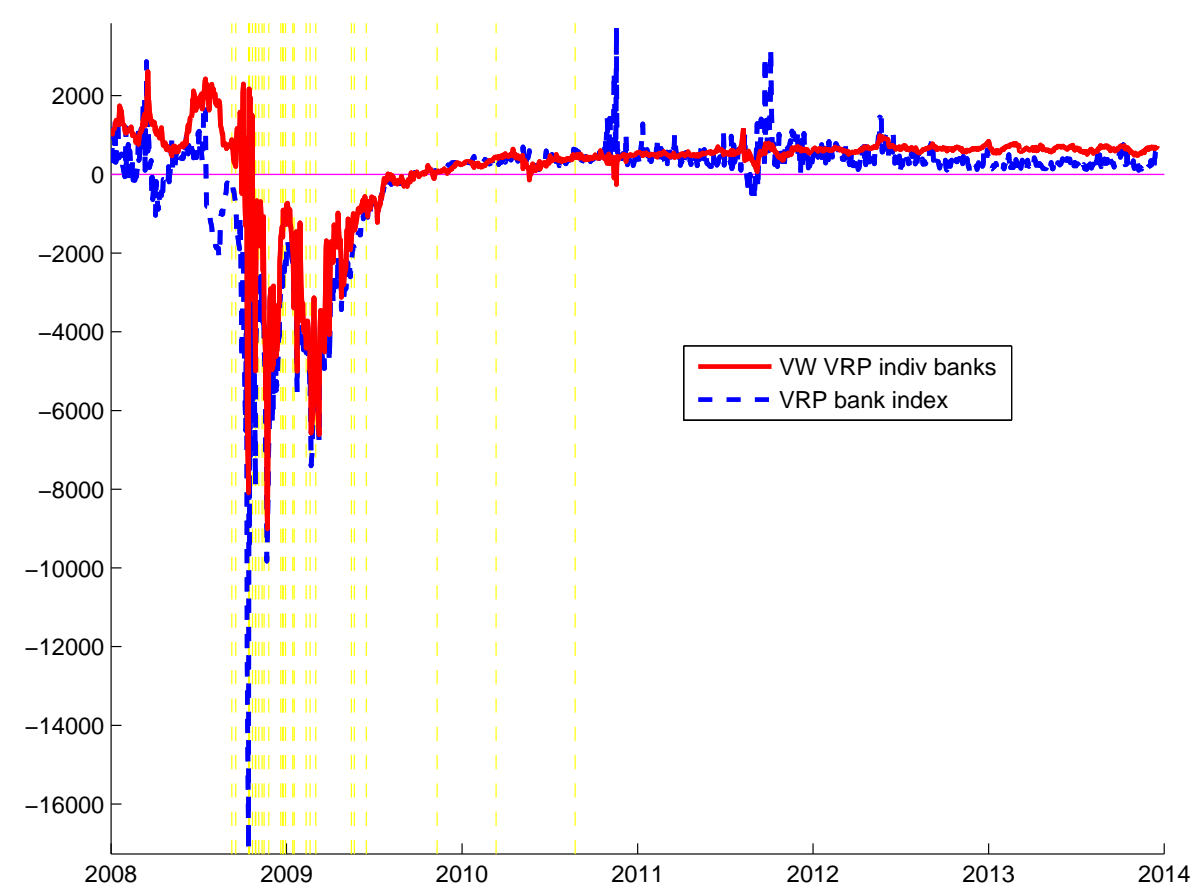

(b) Euro Area

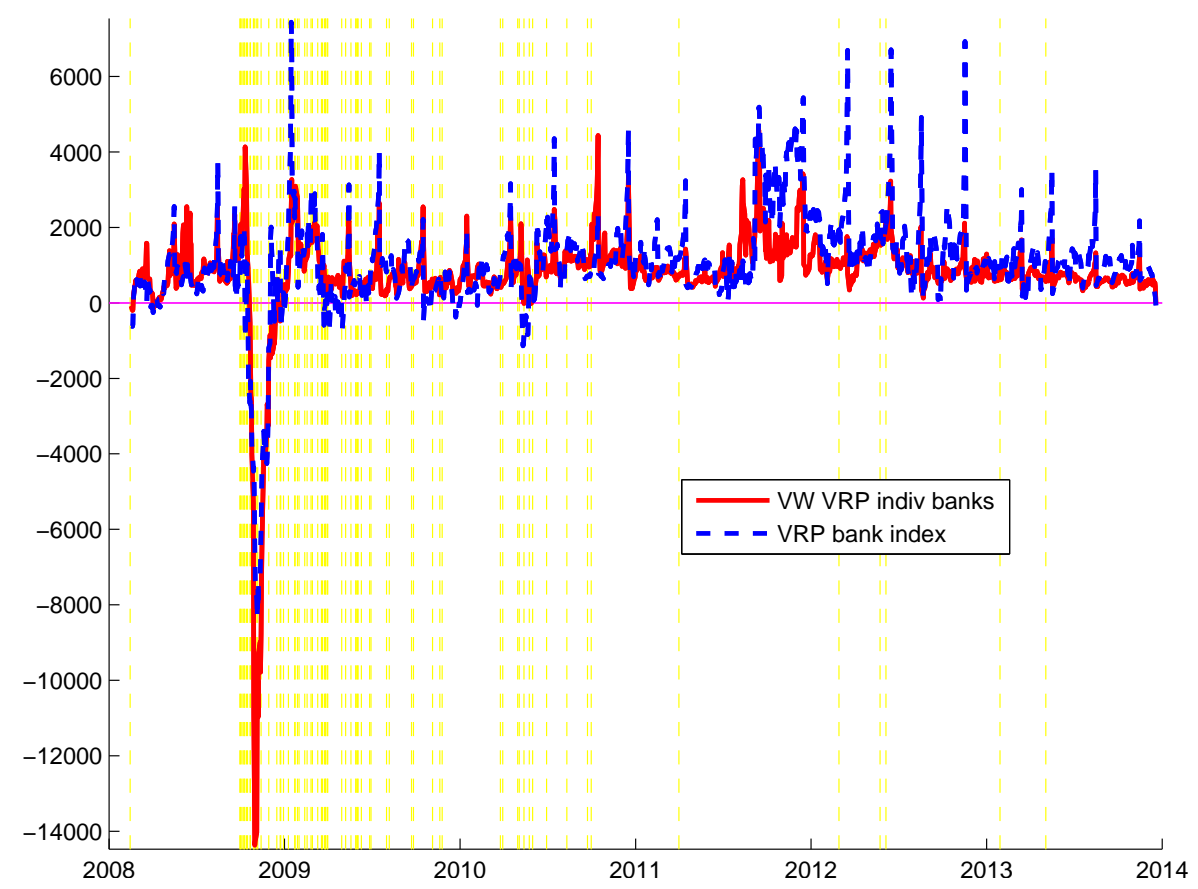


This figure plots the estimated coefficient $c_{U S, h}$ from the following regression:

$$
r p_{U S, t+h}=c_{U S, h} D_{U S, t}+s_{U S, h} S u r p_{U S, t}+\epsilon_{t, h},
$$

for $h=1$ to 30 days after the announcement of a capital injection to a bank in the U.S. The dependent variable is one of the following options-based risk premium measures: (a) downside correlation risk premium (DCRP) for U.S. banks, (b) downside variance risk premium (VRP) of the U.S. bank index (KBW), and (c) relative-volatility-weighted (VW) average of the downside variance risk premiums of individual banks in the bank index. Dummy $D_{U S, t}$ is equal to 1 if there is a capital injection announcement in the U.S. at time $t$, and $S_{u r p}{ }_{U S, t}$ is a measure of macroeconomic news surprises (see Scotti, 2013). The dotted blue lines represent one and two standard error deviations. Standard errors are corrected using Newey and West (1987) with 10 lags.

(a) DCRP

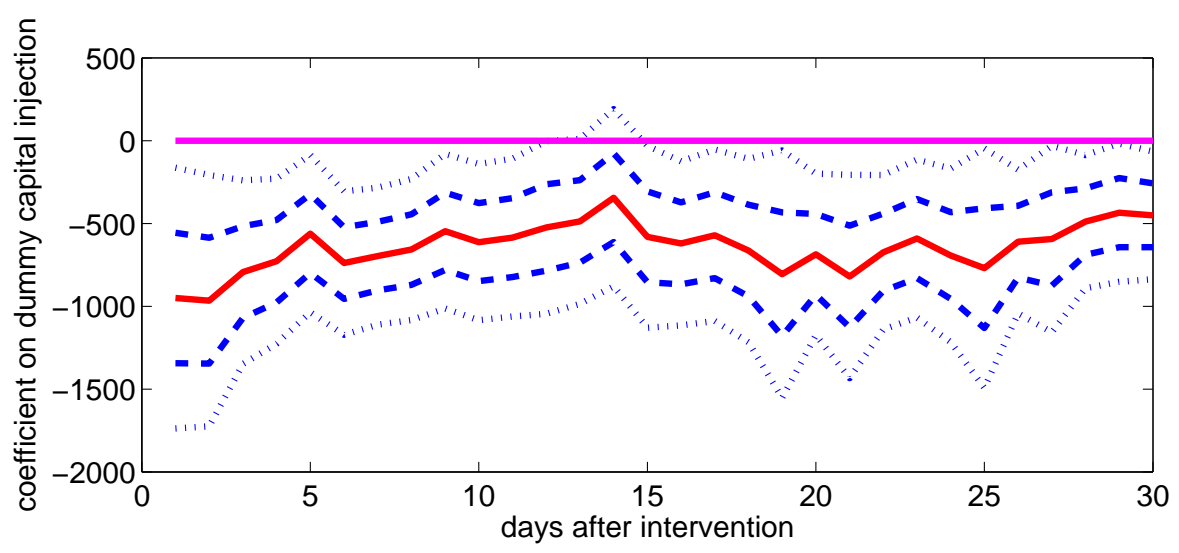

(b) VRP of bank index

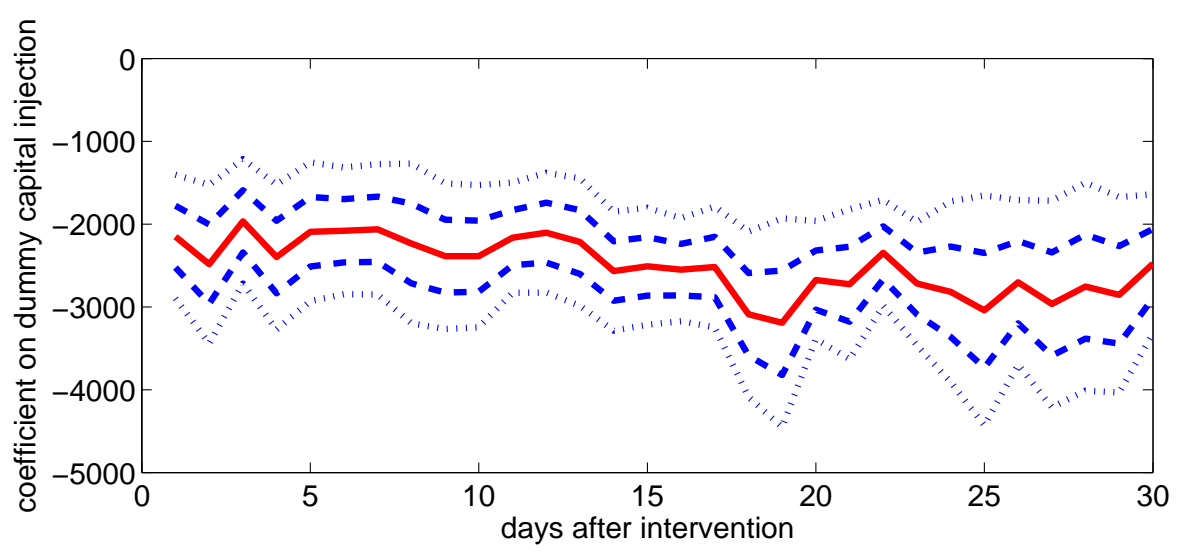

(c) VW average of VRPs of individual banks

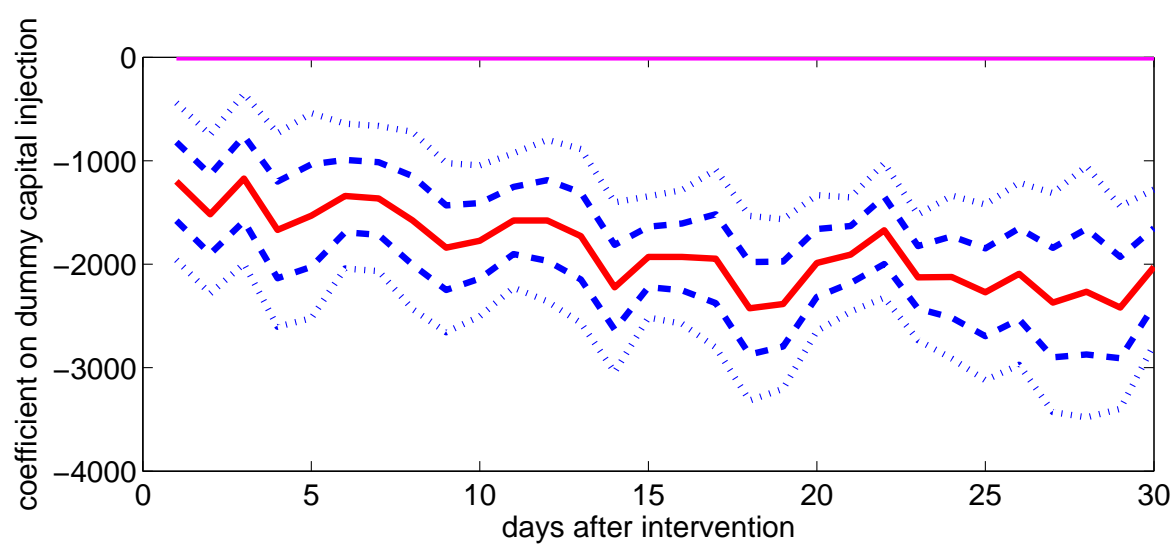


Figure 4: Effect of intervention announcements on euro-area DCRP

This figure plots the estimated coefficient $c_{E u r o, h}$ from the following regression:

$$
r p_{\text {Euro }, t+h}=c_{\text {Euro }, h} D_{\text {Euro }, t}+s_{\text {Euro }, h} \operatorname{Surp}_{\text {Euro }, t}+\epsilon_{t, h}
$$

for $h=1$ to 30 days after the announcement of a capital injection to a bank in the euro area. The dependent variable is one of the following options-based risk premium measures: (a) downside correlation risk premium (DCRP) for euro-area banks, (b) downside variance risk premium (VRP) of the euro-area bank index (Eurostoxx), and (c) relative-volatility-weighted (VW) average of the downside variance risk premiums of individual banks in the bank index. Dummy $D_{E u r o, t}$ is equal to 1 if there is a capital injection announcement in the euro area at time $t$, and $\operatorname{Surp}_{E u r o, t}$ is a measure of macroeconomic news surprises in the euro area (see Scotti, 2013). The dotted blue lines represent one and two standard error deviations. Standard errors are corrected using Newey and West (1987) with 10 lags.

\section{(a) DCRP}

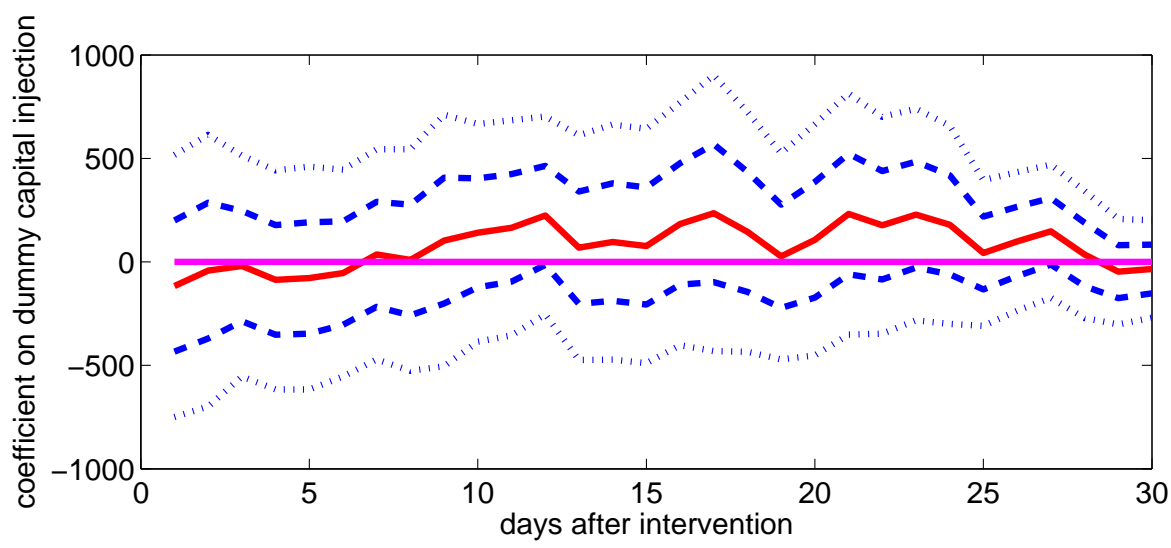

(b) VRP of bank index

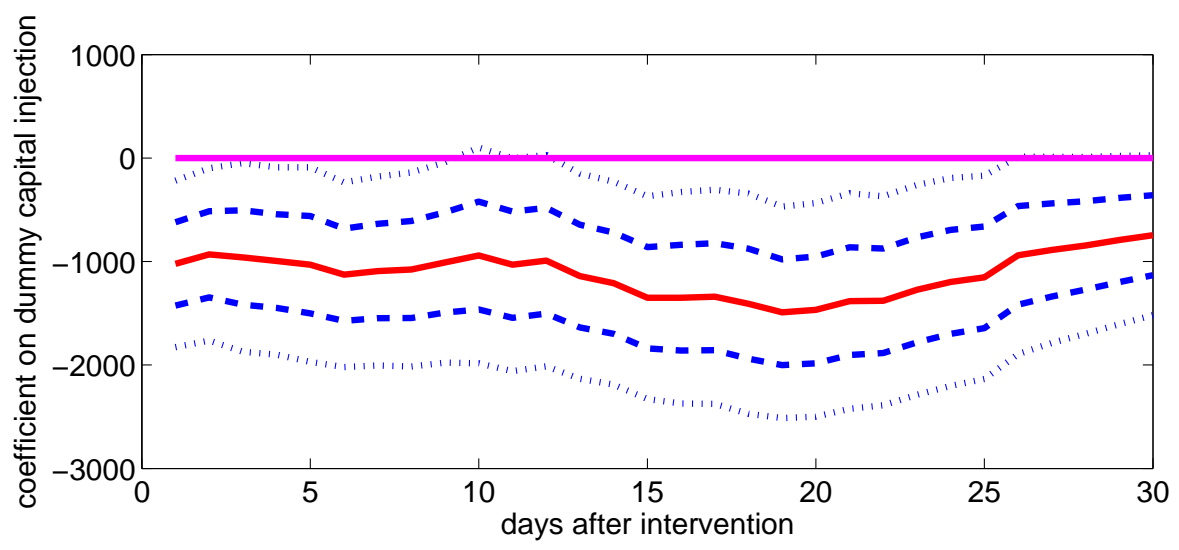

(c) VW average of VRPs of individual banks

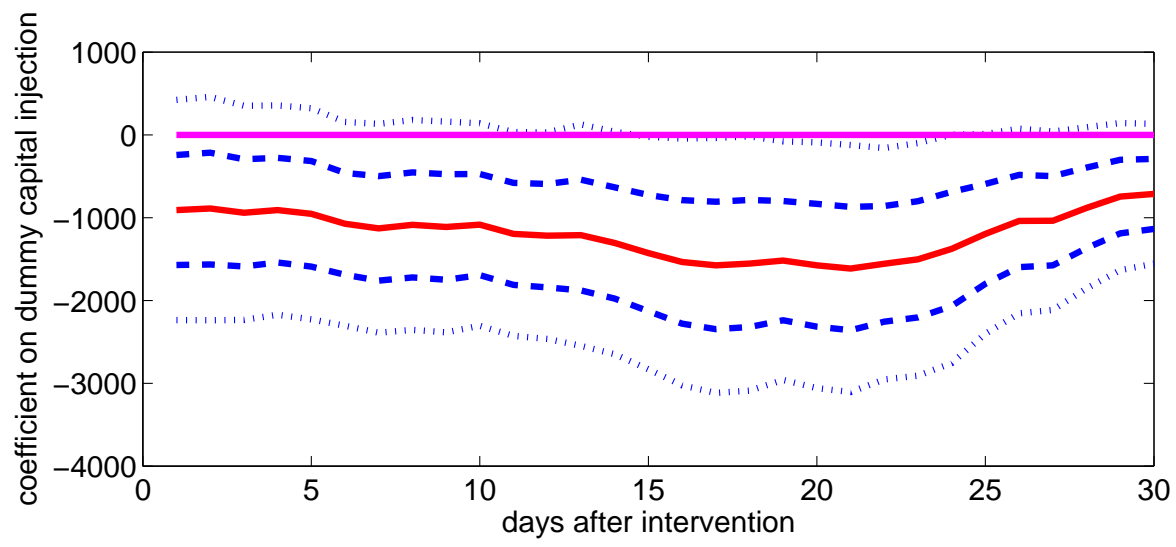




\section{Figure 5: Effect of intervention surprises on DCRP}

This figure plots the estimated coefficient $c_{h}$ from the following regression:

$$
D C R P_{t+h}=c_{h} P_{t}+s_{h} \operatorname{Surp}_{t}+\epsilon_{t, h},
$$

for $h=1$ to 30 days after the announcement of a capital injection to a bank in the U.S. (panel (a)) or in the euro area (panel (b)). DCRP is the downside correlation risk premium. $P_{t}$ represents the likelihood that a capital injection announcement was a surprise to the market. This is calculated as 1 minus the p-value that results from comparing the return of the intervened bank stock in the day following the announcement with a normal distribution of daily returns for the full sample. If stocks of an intervened bank are not publicly traded, the intervention surprise measure is calculated based on the impact of the intervention on the bank index of the country where the bank is domiciled. Surp $t$ is a measure of macroeconomic news surprises (Scotti, 2013). The dotted blue lines represent one and two standard error deviations. Standard errors are corrected using Newey and West (1987) with 10 lags.

(a) U.S.

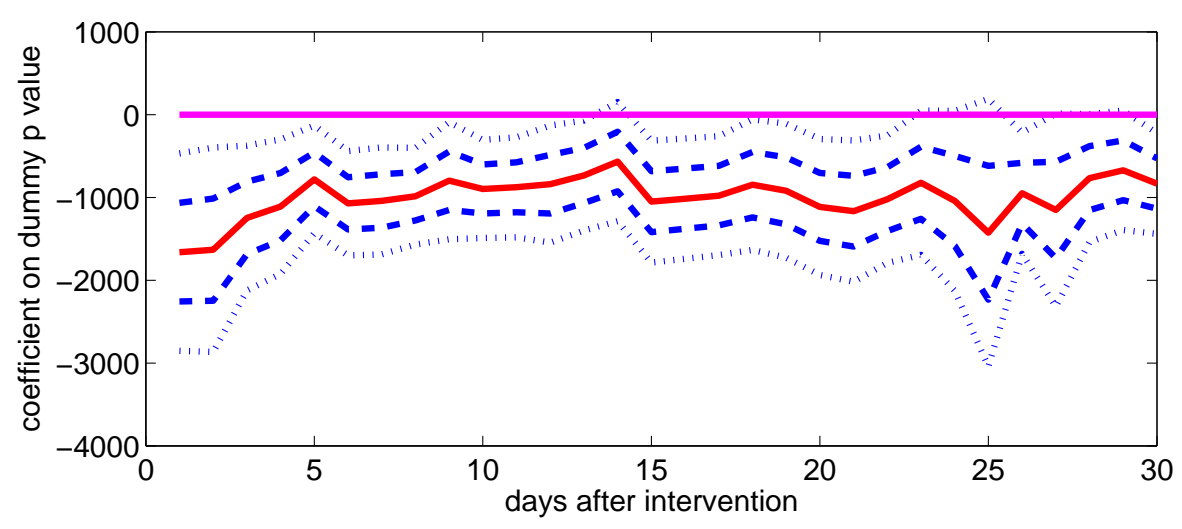

(b) Euro Area

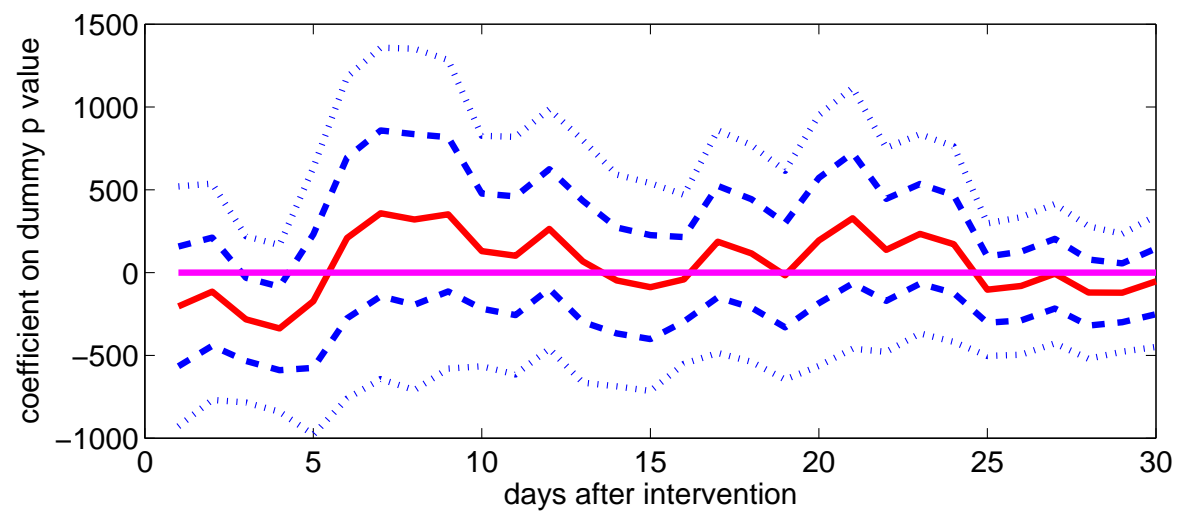


Figure 6: Robustness tests on U.S. DCRP

This figure plots the estimated coefficient $c_{U S, h}$ for alternative specifications of the following regression:

$$
D C R P_{U S, t+h}=c_{U S, h} D_{U S, t}+s_{U S, h} \operatorname{Surp}_{U S, t}+\epsilon_{t, h},
$$

for $h=1$ to 30 days after the announcement of a capital injection. DCRP is the downside correlation risk premium for U.S. banks and dummy $D_{U S, t}$ is equal to 1 if there is a capital injection announcement in the U.S. at time $t$. $\operatorname{Surp}_{U S, t}$ is a measure of macroeconomic news surprises (Scotti, 2013). The dotted blue lines represent one and two standard error deviations. Standard errors are corrected using Newey and West (1987) with 10 lags. Panel (a) shows the results for the subsample 2008-2011. Panel (b) shows the results for a specification where DCRP is calculated using only the 10 largest U.S. banks. Panel (c) is a specification where the downside variance risk premium of the bank index is calculated using options with 90 percent degree of moneyness, while the downside variance risk premiums of the index's components are calculated using options with 80 percent degree of moneyness.

(a) Subsample period: 2008-2011

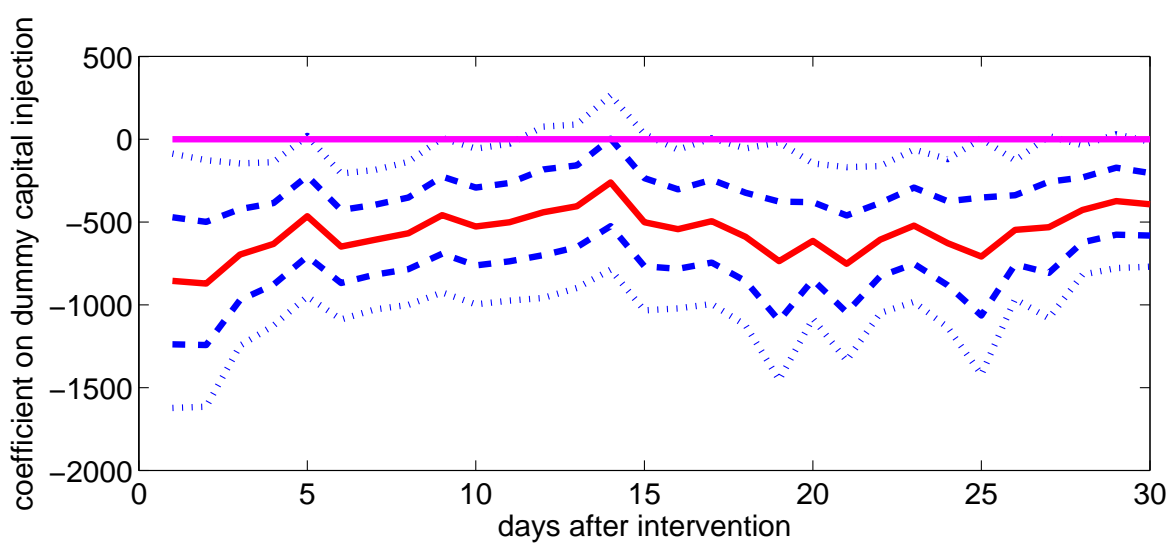

(b) Largest banks

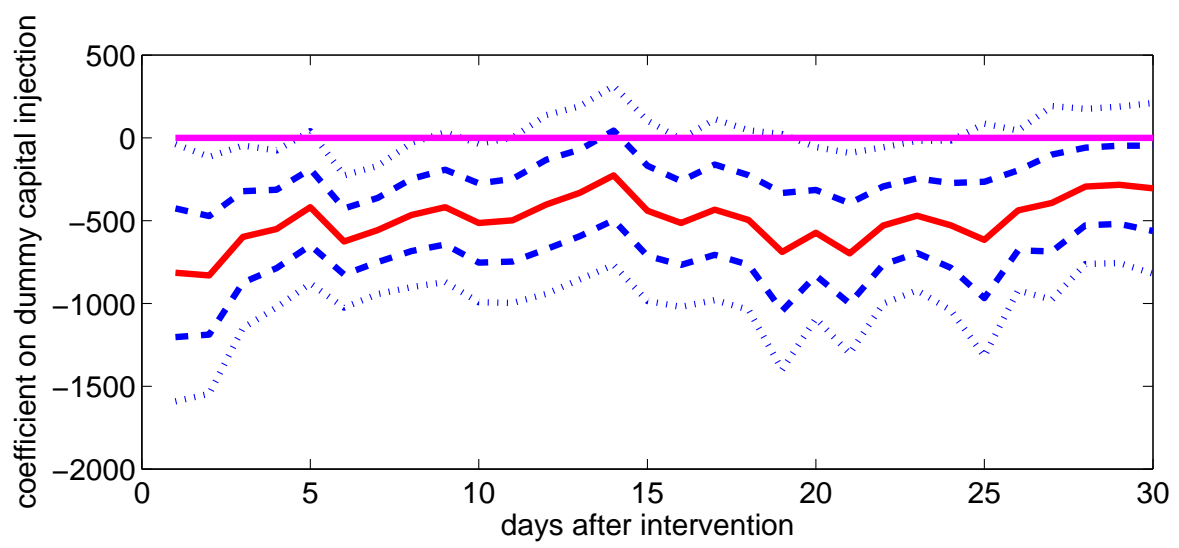

(c) $\operatorname{DCRP}(90,80)$

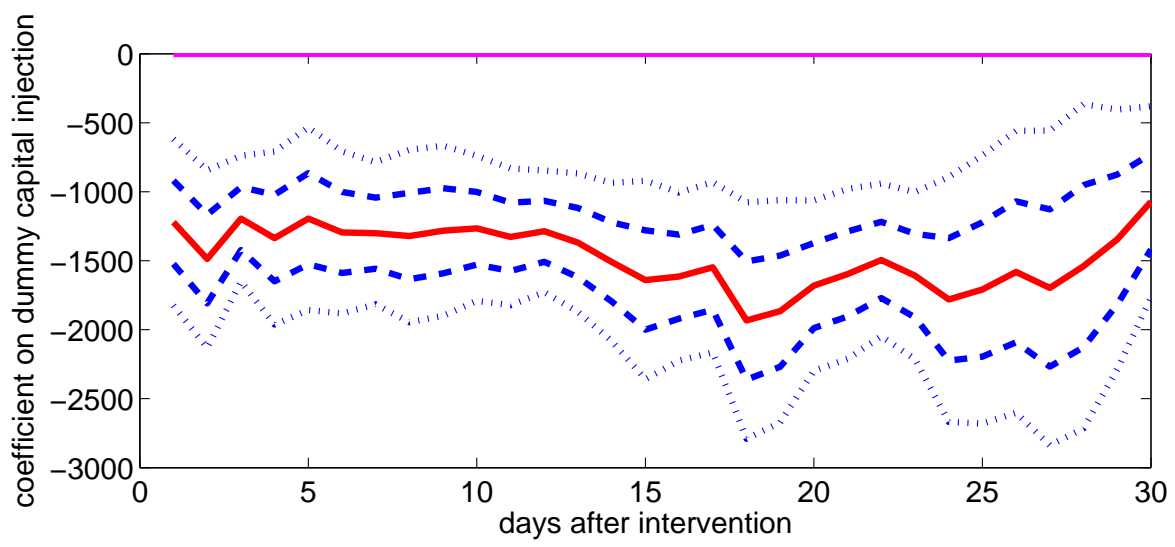


Figure 7: Robustness tests on euro-area DCRP

This figure plots the estimated coefficient $c_{E u r o, h}$ for alternative specifications of the following regression:

$$
D C R P_{\text {Euro }, t+h}=c_{\text {Euro }, h} D_{\text {Euro }, t}+s_{\text {Euro }, h} \operatorname{Surp}_{\text {Euro }, t}+\epsilon_{t, h},
$$

for $h=1$ to 30 days after the announcement of a capital injection. DCRP is the downside correlation risk premium for euro-area banks and dummy $D_{\text {Euro, } t}$ is equal to 1 if there is a capital injection announcement

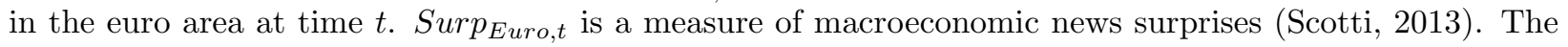
dotted blue lines represent one and two standard error deviations. Standard errors are corrected using Newey and West (1987) with 10 lags. Panel (a) shows the results for the subsample 2008-2011. Panel (b) shows the results for a specification where DCRP is calculated using only the 10 largest U.S. banks. Panel (c) is a specification where the downside variance risk premium of the bank index is calculated using options with 90 percent degree of moneyness, while the downside variance risk premiums of the index's components are calculated using options with 80 percent degree of moneyness.

(a) Subsample period: 2008-2011

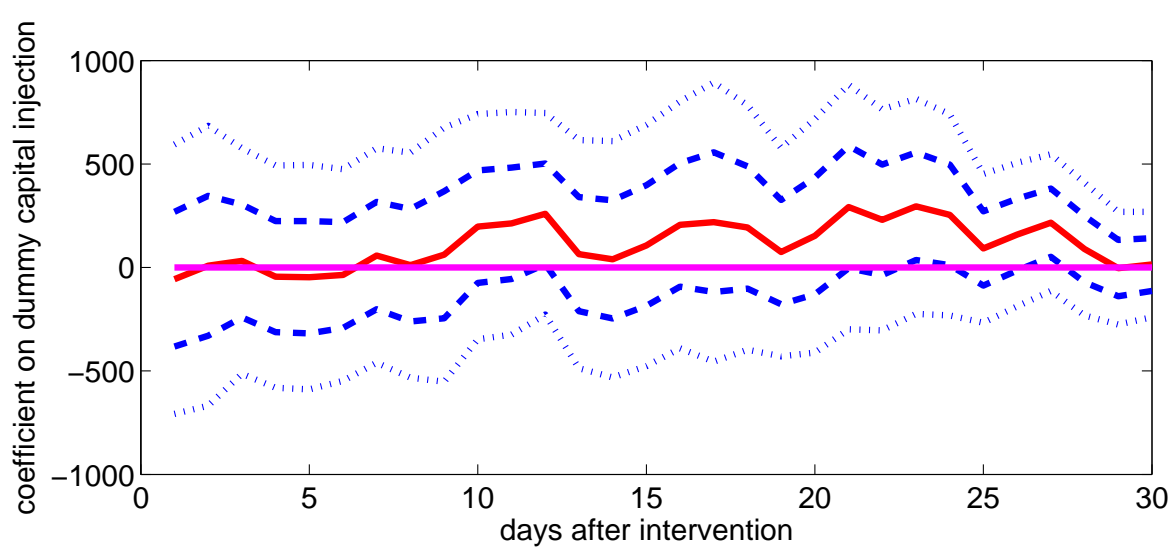

(b) Largest banks

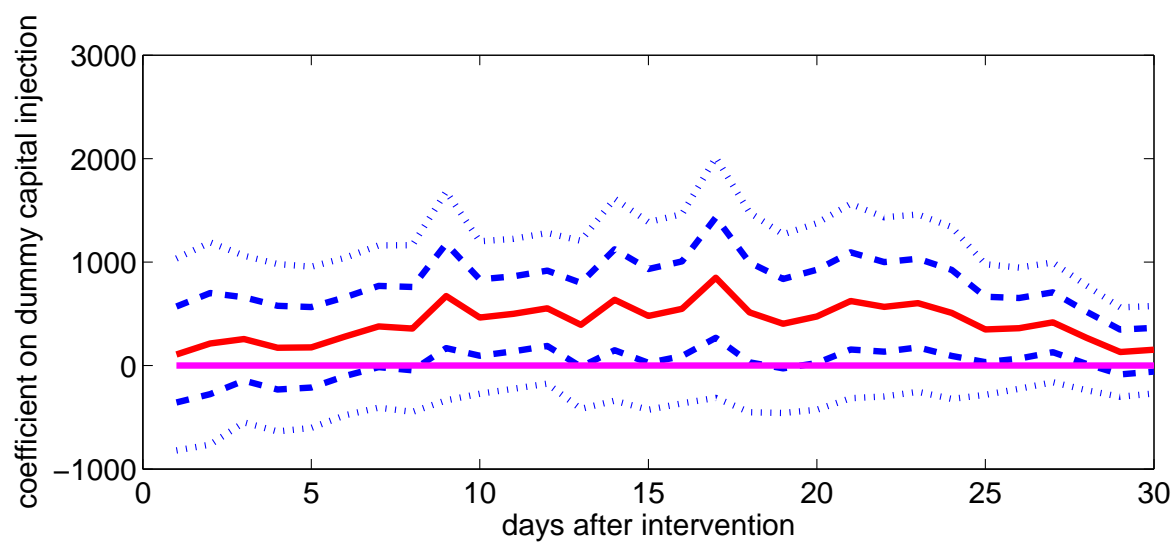

(c) $\operatorname{DCRP}(90,80)$

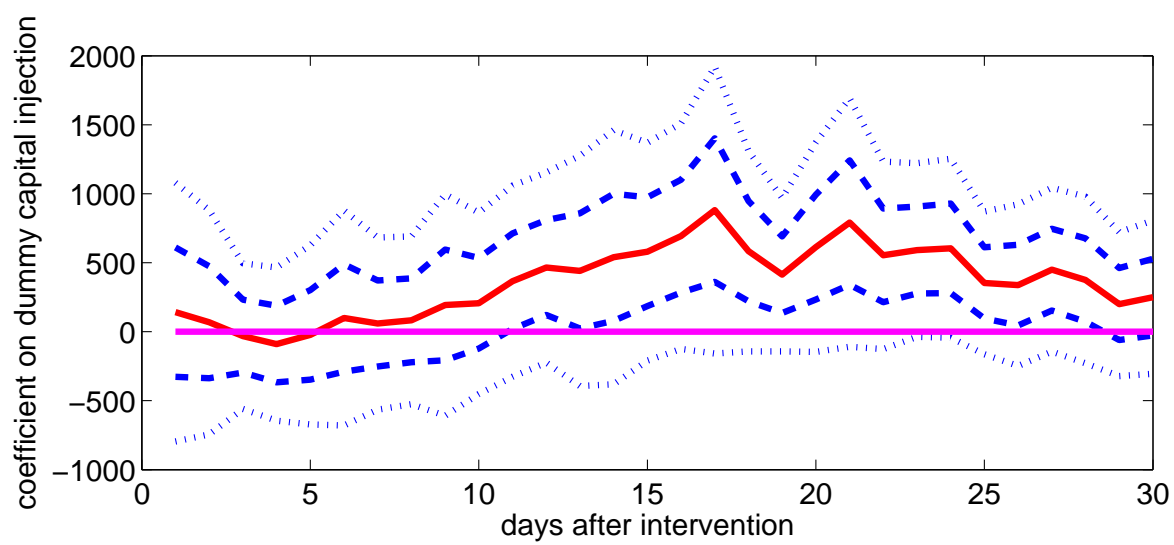




\section{Figure 8: Effect of country-specific bank interventions on euro-area DCRP}

This figure plots the estimated coefficients $c_{i, h}$ from the following regression:

$$
D C R P_{t+h}^{\text {Euro }}=\sum_{i} c_{i, h} D_{i, t}+s_{\text {Euro }, h} \operatorname{Surp}_{\text {Euro }, t}+\epsilon_{t, h},
$$

for $h=1$ to 30 days after an intervention announcement, where $i$ is each one of the following euro-area member states: Belgium, France, Germany, Greece, Italy, Netherlands, Spain, and rest of the euro area. The dependent variable is the euro-area DCRP, dummy $D_{i, t}$ is equal to 1 if there is a capital injection announcement in country $i$ at time $t$, and $\operatorname{Surp}_{\text {Euro, } t}$ is a measure of macroeconomic news surprises in the euro area $(($ Scotti, 2013) $)$. In each panel, the solid red line plots the coefficient from the joint regression on $D_{i, t}$ for all countries, while the dotted green line plots the coefficient from regressing on only $D_{i, t}$ for the country in the panel $\left(E C R P_{t+h}^{\text {Euro }}=c_{i, h} D_{i, t}+s_{\text {Euro }, h} \operatorname{Surp}_{\text {Euro }, t}+\epsilon_{t, h}\right)$. The dotted blue lines represent one and two standard error deviations for the former specification. Standard errors are corrected using Newey and West (1987) with 10 lags.

(a) Belgium

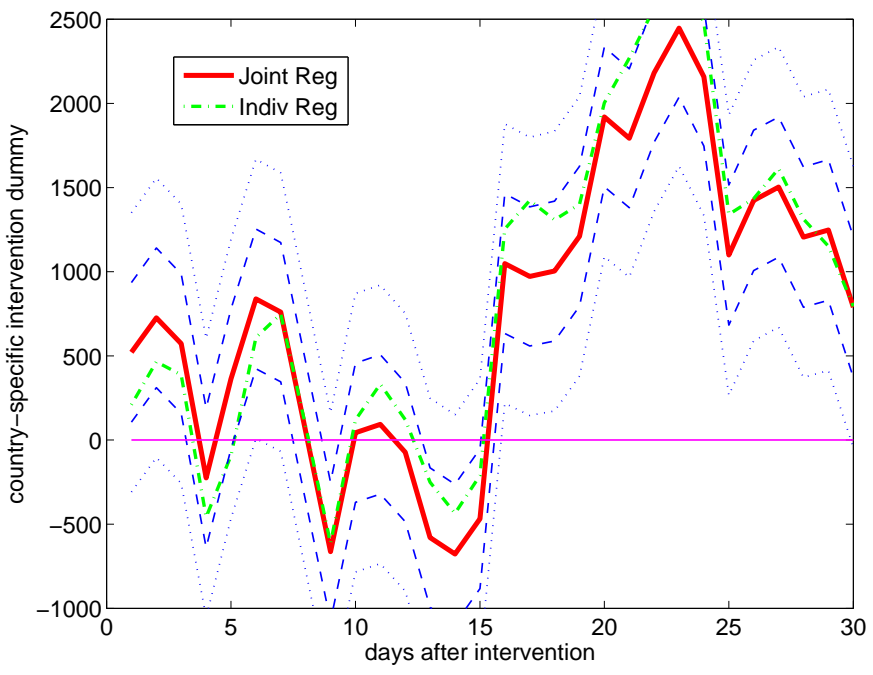

(c) Germany

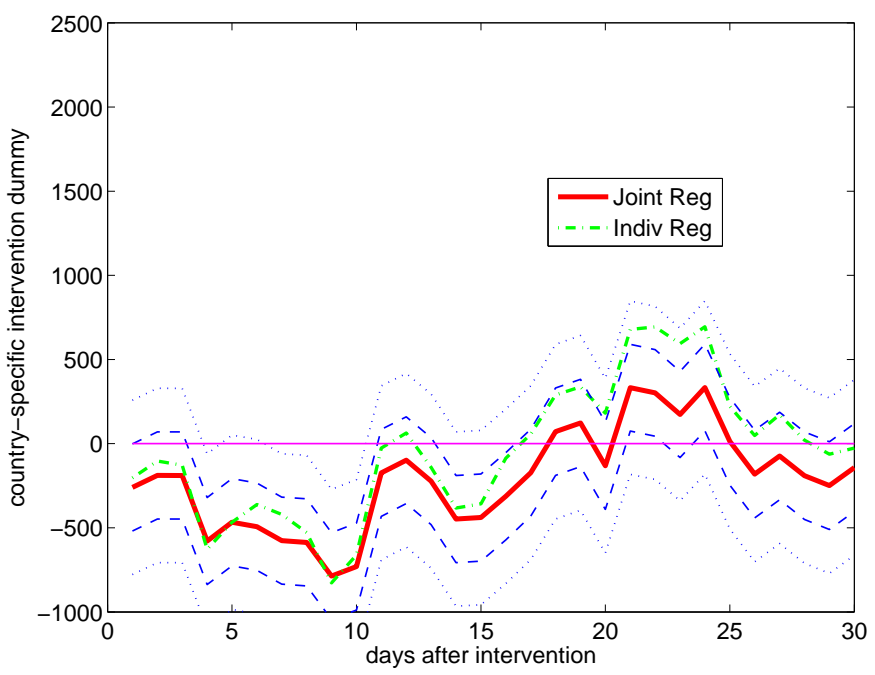

(b) France

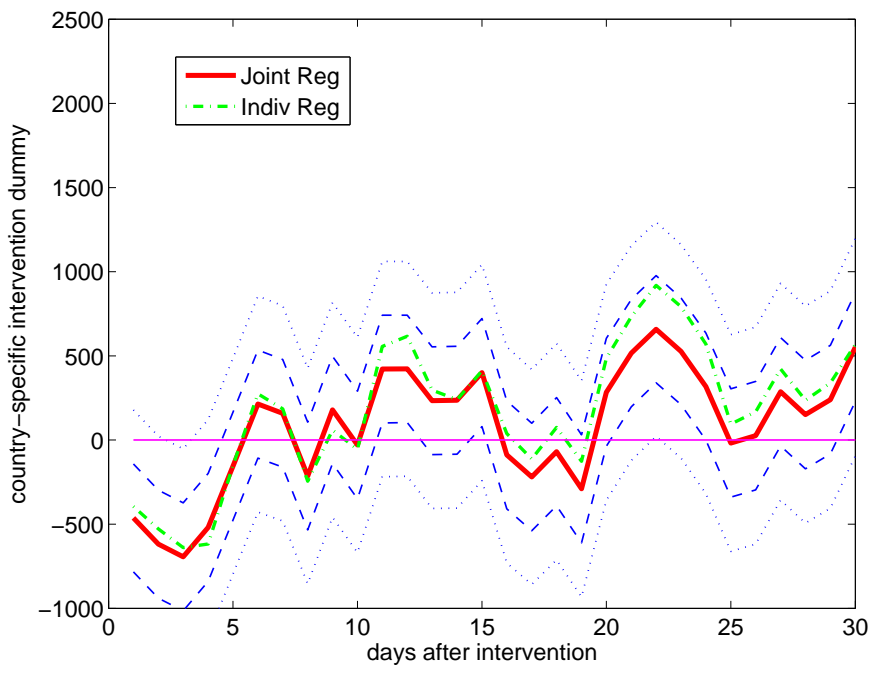

(d) Greece

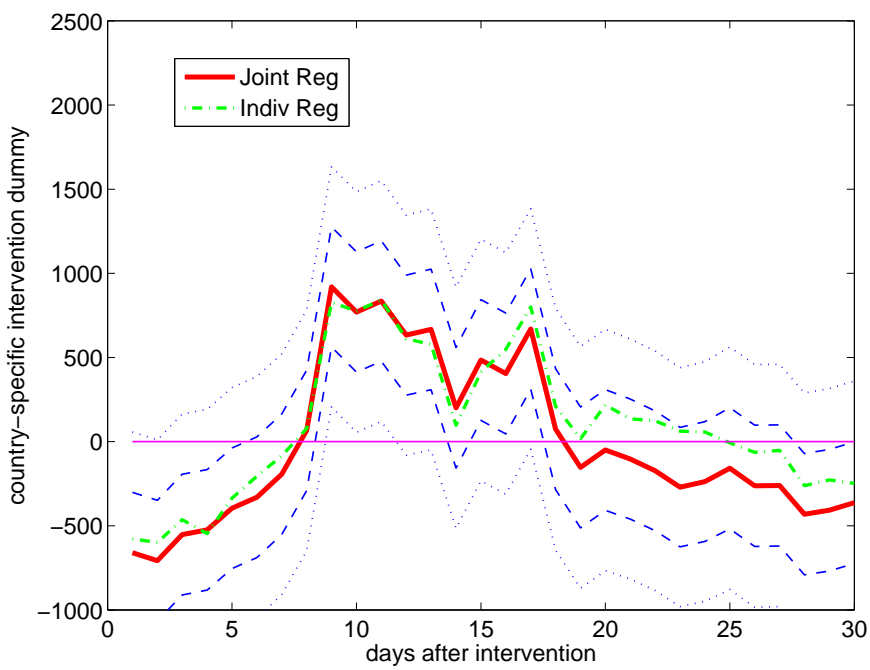


Figure 8: Effect of country-specific bank interventions on euro-area DCRP, continued

(e) Italy

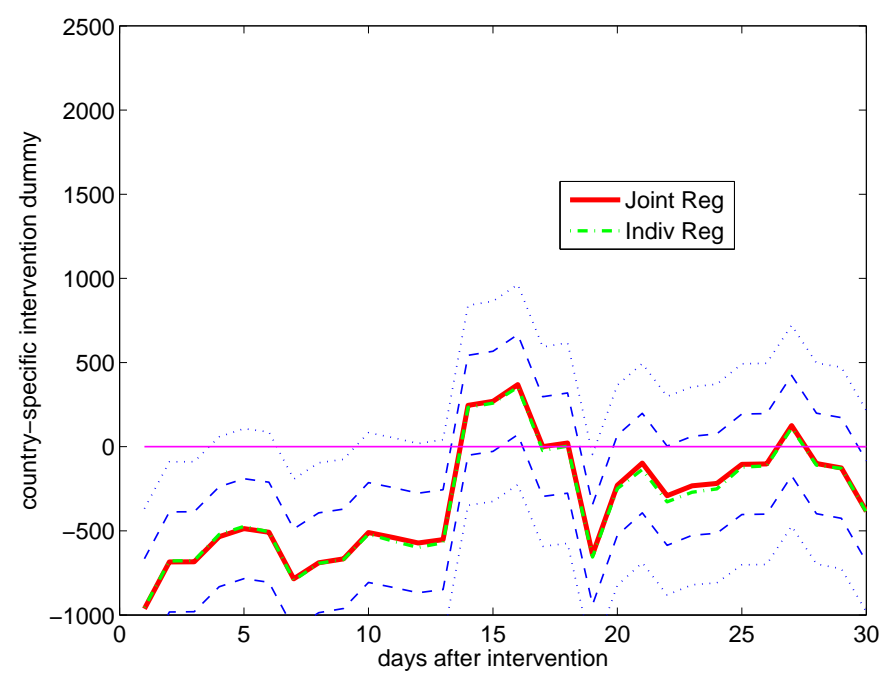

(g) Spain

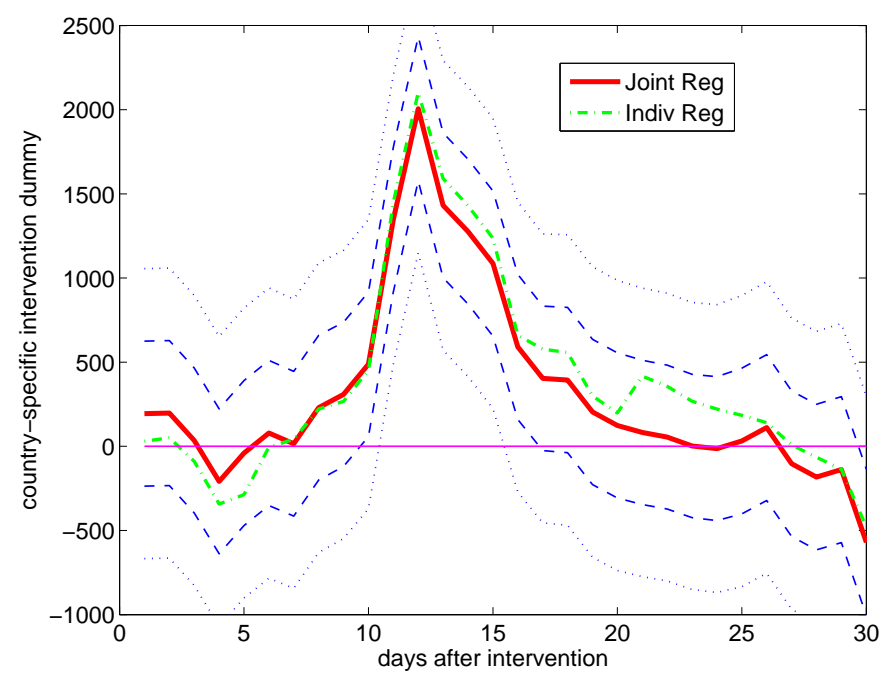

(f) Netherlands

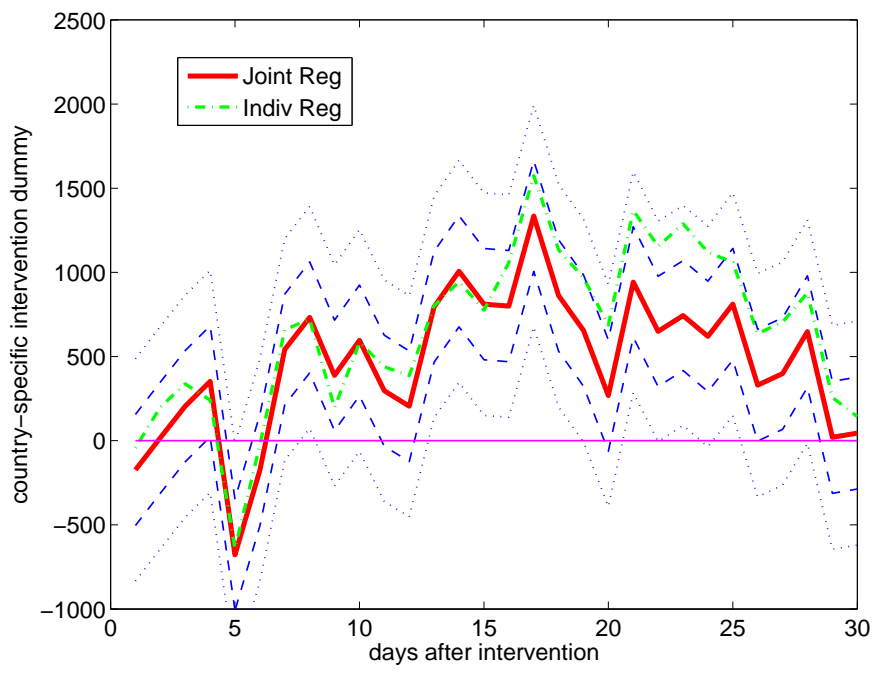

(h) Rest of Euro-area

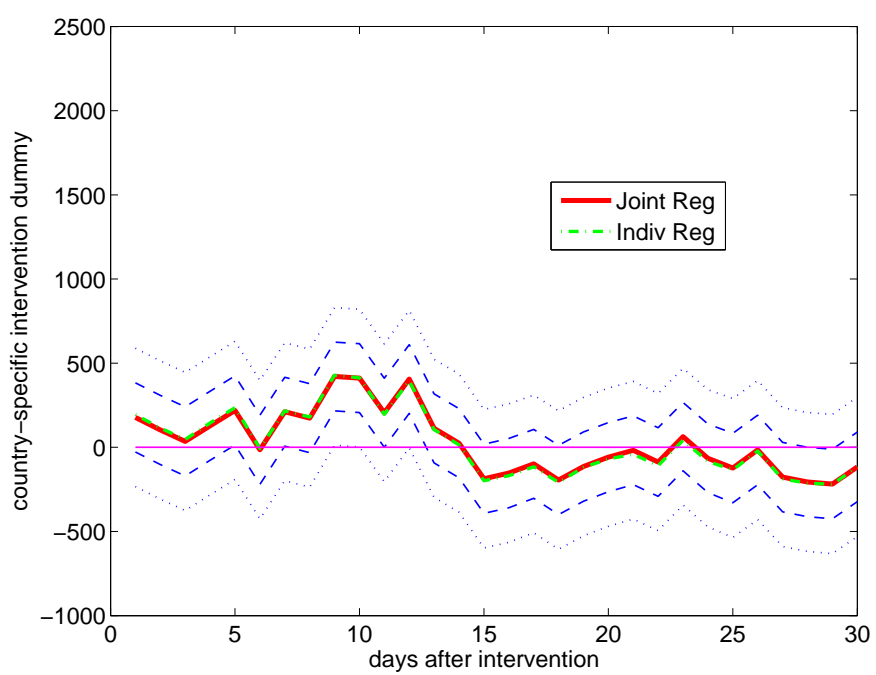

